\title{
Curcumin-based-fluorescent probes targeting ALDH1A3 as a promising tool for glioblastoma precision surgery and early diagnosis
}

\section{Edoardo Gelardi}

University of Piemonte Orientale

Diego Caprioglio

University of Piemonte Orientale

Giorgia Colombo

University of Piemonte Orientale

Daniele Mazzoletti

University of Piemonte Orientale

\section{Daiana Mattoteia}

University of Piemonte Orientale

\section{Stefano Salamone}

University of Piemonte Orientale

\section{Davide Ferraris}

University of Piemonte Orientale

\section{Eleonora Aronica}

University of Amsterdam

\section{Giulia Nato}

University of Turin

Annalisa Buffo

Universita degli Studi di Torino https://orcid.org/0000-0001-7637-0006

Menico Rizzi

University of Piemonte Orientale

Lorenzo Magrassi

University of Pavia

Alberto Minassi

University of Piemonte Orientale

Silvia Garavaglia ( $\nabla$ silvia.garavaglia@uniupo.it )

University of Piemonte Orientale https://orcid.org/0000-0001-8494-1729 
Keywords: High Grade Glioma (HGG). surgical oncology, brain tumour

Posted Date: June 8th, 2021

DOI: https://doi.org/10.21203/rs.3.rs-567295/v1

License: (c) (1) This work is licensed under a Creative Commons Attribution 4.0 International License. Read Full License

Version of Record: A version of this preprint was published at Communications Biology on September 1st, 2022. See the published version at https://doi.org/10.1038/s42003-022-03834-7. 


\section{Curcumin-based-fluorescent probes targeting ALDH1A3 as a promising tool for glioblastoma precision surgery and early diagnosis}

Edoardo L. M. Gelardia, ${ }^{\mathrm{a},}$, Diego Caprioglio ${ }^{\mathrm{a}, 1}$, Giorgia Colombo ${ }^{\mathrm{a}}$, Daniele Mazzoletti $^{a}$, Daiana Mattoteia ${ }^{a}$, Stefano Salamone ${ }^{a}$, Davide M. Ferraris ${ }^{a, h}$, Eleonora Aronica ${ }^{b, c}$, Giulia Nato ${ }^{\mathrm{d}, \mathrm{e}}$, Annalisa Buffo,e, Menico Rizzi ${ }^{\mathrm{f}}$, Lorenzo Magrassi $^{\mathrm{g}, \mathrm{h}}$, Alberto Minassi ${ }^{\mathrm{a},{ }^{*}}$ \& Silvia Garavaglia ${ }^{\mathrm{a},{ }^{,}}$.

${ }^{a}$ Department of Scienze del Farmaco, University of Piemonte Orientale, Via Bovio, 6 , Novara, 28100, Italy

${ }^{b}$ Department of (Neuro)Pathology, Amsterdam UMC, University of Amsterdam, The Netherlands

${ }^{c}$ Stichting Epilepsie Instellingen Nederland (SEIN), Heemstede, The Netherlands

d Department of Life Sciences and System Biology University of Turin, Via accademia Albertina 13,Turin, Italy

e Neuroscience Institute Cavalieri Ottolenghi (NICO), 10043 Orbassano, Torino, Italy.

${ }^{f}$ Department of Neuroscience Rita Levi Montalcini, University of Turin, Via Cherasco 15, Torino, Italy.

g Neurosurgery, Department of Clinical, Surgical, Diagnostic and Pediatric Science, University of Pavia, Foundation IRCCS Policlinico San Matteo, Pavia, 27100, Italy.

h Istituto Di Genetica Molecolare IGM-CNR, via Abbiategrasso 207, 27100 Pavia, Italy.

' PlantaChem srls, via Canobio 4/6, 28100 Novara, Italy

h IXTAL srl, via Bovio 6, 28100, Novara, Italy

Correspondence: silvia.garavaglia@uniupo.it; alberto.minassi@uniupo.it

${ }^{1}$ These authors contributed equally to the work

${ }^{2}$ Co-last authors with Prof. Silvia Garavaglia 


\begin{abstract}
High Grade Glioma (HGG) is the most aggressive primary brain tumour for which both effective treatments and efficient tools for an early-stage diagnosis are lacking. Herein, we present two curcumin-based fluorescent probes that are able to bind to aldehyde dehydrogenase $1 \mathrm{~A} 3$ (ALDH1A3), an enzyme overexpressed in glioma stem cells (GSCs) and associated with stemness and invasiveness of HGG. Both compounds are selective versus ALDH1A3, without showing any appreciable interaction with other ALDH1A isoenzymes. Indeed, their fluorescent signal is detectable only in our positive controls in vitro and absent in cells that lack ALDH1A3. Remarkably, in vivo, they selectively accumulate in glioblastoma cells, allowing the identification of the growing tumour mass. The significant specificity of our compounds is the necessary premise for their further development into glioblastoma cells detecting probes to be possibly used during neurosurgical operations.
\end{abstract}




\section{Introduction}

The term Glioma refers to a class of primary brain tumours that represent the $40 \%$ of all brain tumours. Gliomas can be classified on the basis of their histological subtypes: the astrocytoma, which is the most common, the oligodendroglioma and the ependymoma. They can be further divided into LowGrade Gliomas (LGGs) and into High-Grade Gliomas (HGGs), based on their malignancy ${ }^{1} \mathrm{HGGs}$ are the most invasive and are associated with a high ability to metastasize, with an extremely fast cell growth, a marked chemoresistance and a poor clinical outcome ${ }^{2}$. Their marked drug resistance is related to the presence of a high density of cancer stem cells (CSCs) that possess self-renewal ability and an unlimited proliferative potential, just like their physiological counterparts ${ }^{3,4}$. Glioma stem cells (GSCs) also provide the tumour with an enhanced resistance to drugs, radiation and oxidative stress, thus increasing HGG resistence to treatments, and their presence is associated with metastasis and relapse. Moreover, mesenchymal GSCs (Mes-GSCs) proved to be significantly more radioresistant than proneural GSCs (PN-GSCs) ${ }^{5-8}$. It has been demonstrated that the radiation treatment can induce the phenotype shift from PN to Mes, set out by the loss of the PN marker SOX2 and by the expression of the Mes marker CD44 ${ }^{9}$. The tumours that are rich in Mes GSCs are the deadliest, the most dangerous and the most susceptible to relapse. As far as the tumorigenic behaviour is concerned, Mes-GSCs showcased a higher growth potential under identical conditions compared to PN-GSCs both in vitro and in vivo ${ }^{10}$. The only resolutive treatment is the surgery that, when possible, allows the complete resection of the main tumour, when possible ${ }^{11,12}$. Even with this approach, though, the patient lifespan is around 5 years. This is the reason why the development of innovative tools for an early diagnosis and for the chemo treatment is of the utmost importance. In a paper published by Zhang et al. in $2015^{13}$, a transcriptomic analysis highlights the enrichment of the cytoplasmatic enzyme aldehyde dehydrogenase 1A3 (ALDH1A3) in Mes-GSCs. ALDH1A3 belongs to an enzymatic superfamily of aldehyde dehydrogenases, composed of 
19 different isoforms, and involved in the irreversible $\mathrm{NAD}^{+}$-dependent oxidation of a wide range of aldehydes ${ }^{14}$. This superfamily is also involved in the reduction of oxidative stress and in the metabolism of several drugs, such as cyclophosphamide ${ }^{15}$. ALDH1A3 belongs to the ALDH1A superfamily, that also includes ALDH1A1 and $1 \mathrm{~A} 2$. All three isoenzymes are involved in the oxidation of retinal to retinoic acid, a molecule that is essential for tissue differentiation and cellular development ${ }^{16,17}$. ALDH1A1 and ALDH1A3 have been described as important markers ${ }^{18,19}$ and targets ${ }^{20-22}$ of CSCs in a wide variety of tumours. A great number of evidence acknowledge ALDH1A3 as the hallmark of the GSCs Mes-subtype, which may play an important role in glioma malignancy, given that it is involved in stem cell viability and in tumour invasion ${ }^{23}$. Considering the wellknown catalytic function of ALDHs, they are regarded as the key enzymes that can detoxify harmful aldehydes within the organism, and this could be the reason why so many cytotoxic antineoplastic molecules are inactivated by CSCs ${ }^{24-26}$. As a result, ALDH1A1 and ALDH1A3 may protect CSCs from antineoplastic molecules, their levels could represent a prognostic factor that could anticipate the chemotherapy efficacy and their inactivation could make the tumour cells susceptible to medical treatments ${ }^{27-29}$. Since CSCs started to be considered as one of the key mechanisms used by the tumour to evade chemotherapy and radiation treatment, researchers decided to focus their attention on finding a way to selectively target this cellular subpopulation, that could help improve alreadyexisting therapies and prevent the relapse of the tumour.

Curcumin is the most famous and most abundant congener of curcuminoids, a class of bioactive compounds isolated from turmeric (Curcuma longa L.) and commonly used for flavouring food in the Southeast Asian and Middle Eastern countries. Nowadays it is used in the food industry as coloring agent known as E100. In the past decade, this natural dye became one of the best candidates for the development of new therapies against gliomas ${ }^{30}$. The antineoplastic abilities of curcumin, such as the induction of apoptosis and the inhibition of proliferation and invasion, have been proved in several tumours, 
including gliomas. Curcumin is also capable of inducing reactive oxygen species (ROS) in a wide variety of cancers, so as to lead to the activation of the MAPK apoptotic pathway ${ }^{31}$. Even though CSCs radical scavenging systems have been reported, several studies confirmed that curcumin-induced ROS can target GSCs 32. However, this plethora of bioactivities should be viewed with scepticism: curcumin is one of the most famous Pan-Assay Interference Compounds (PAINs), exhibiting all known behaviours of this class of molecules and confining it to a mere academic curiosity ${ }^{33}$. Besides the well-known health-promoting benefits, curcumin also possesses a strong intrinsic fluorescence and some of its derivatives have recently been acknowledged as optical probes for the in vivo studies of several diseases, such as Alzheimer ${ }^{34}$ and solid tumour ${ }^{35,36}$. To date, as the surgical resection of the tumour mass is the only resolutive treatment for HGGs, having a tool that could lead to an early diagnosis and improve the surgeon accuracy during the operation would be a great advantage ${ }^{37}$. Therefore, a fluorescent probe that can detect a mass of CSCs within the brain of a patient with glioma could be extremely helpful and useful. In this paper, we present the first study of two different selective ALDH1A3 fluorescent probes, with a curcumin scaffold-based nature, that are able to inhibit the activity of the recombinant enzyme and can be detectable only in our positive controls, both in vitro and in vivo.

\section{Results and Discussion}

\section{Chemistry}

In this project we propose the synthesis of a class of curcumin-based probes where a triazole moiety is used as connector between the fluorescent dye and the functional group needed for the interaction with the active site of the enzyme. Since we already worked on the curcumin scaffold ${ }^{38-41}$, we identified five key synthons as starting points: the hemi-curcuminoids 4 and 5, the O-propargylvanillin (3) and the azido derivatives 8 and 9. 
Compounds 4 and 5 were easily obtained condensing respectively vanillin (1) and 4-(dimethylamino)benzaldehyde (2) with acetylacetone under Pabon conditions 42. The replacement of the vanillic moiety with a dimetylamino group was done to modulate the fluorescence emission ${ }^{43}$ and, in the attempt to enhance the solubility of the final compound.

A second Pabon condensation of hemi-curcuminoids $\mathbf{4}$ and $\mathbf{5}$ with O-propargylvanillin (3), furnished respectively compounds 6 and $\mathbf{7}$ that underwent to a copper catalyzed Huisgen [3+2] cycloaddition with 8 and 9 leading compounds 10, 11 and 12. Given the possible solubility problems due to the presence of a triazole moiety together with a curcuminoid sub-structure ${ }^{44,45}$, compounds 10 and $\mathbf{1 1}$ were phosphorylated using diethylchlorophosphate in presence of triethylamine affording compounds 13 and 14 (Figure1).

\section{Biochemical characterization of probe 10 and probe 11 with recombinant human ALDH1A3}

All five fluorescent compounds were firstly characterized for their solubility in physiological buffer and for their absorbance values. We then performed a 3D analysis using a TECAN SPARK to simultaneously evaluate the excitation and the emission wavelengths, that were supposed to be like the curcumin ones ${ }^{46}$. Between all five molecules, the compounds 10 and 11 showed major solubility and the fluorescence values were similar to the not substituted fluorophore. For that, we decided to continue the biochemical characterization on probe 10 and 11 using the selected parameters (Figures $2 \mathrm{~A}$ and $3 \mathrm{~A}$ ). The fluorescent signal changes of both molecules were firstly evaluated in complex with recombinant human ALDH1A3. Prior to the interaction with the target protein, the two probes possess an intrinsic low fluorescence emission, but the subsequent addition of ALDH1A3 to the mix leads to a consistent increase in the intensity of the fluorescent signal of about 12 folds for probe 10 and 8 folds for probe 11 (Figures $2 \mathrm{~B}$ and $3 \mathrm{~B}$ ). To better characterized our fluorescent compounds, we tested their potential cross-reactivity towards the other two isoforms of the ALDH1A 
subfamily. As show in Figure 2B, probe 10 exhibits low cross-reactivity with other two isoform, about 2 folds for ALDH1A1 and 4 folds for ALDH1A2, showing a strong selectivity versus ALDH1A3. In addition, a wide range of biologically relevant analytes were tested in complex, with a fixed concentration of $10 \mu \mathrm{M}$ of both probes, to make sure that none of the off-target signals could affect the analysis. None of the selected compounds generated significant fluorescent signals, compared with the positive controls (Figure 2B). We started to characterize the affinity of compound $\mathbf{1 0}$ with the different isoenzyme. We tested a fix amount of probe $\mathbf{1 0}$ with different protein concentrations and, surprisingly, the molecule showed the same $\mathrm{K}_{d}$ values among all three enzymes (Figure $2 \mathrm{C}$ ). To clearly understand the nature of the probe 10-ALDH1A3 complex, we tested our fluorescent compound as an inhibitor, using an already published protocol. As showed in Figures $2 \mathrm{D}$ and $1 \mathrm{E}, \mathrm{ALDH} 1 \mathrm{~A} 3$ turned out to be the only strongly inhibited protein with a $K_{i}$ value of $880 \mathrm{nM}$, with a competitive mechanism of action. Besides, neither of the two enzymes was inhibited, even at the highest probe concentration used to test the catalytic activities of ALDH1A1 and $A L D H 1 A 2$. Probe $\mathbf{1 0}$ was also tested as a possible substrate, due to the presence of a benzaldehyde on the lateral chain of the fluorophore (Figure 2E). The compound was fully metabolized and converted to its carboxylic derivative by both ALDH1A1 and 1A2, yet ALDH1A3 was not able to oxidize it. More specifically, the isoform $1 A 3$ is inhibited by probe 10 in the low micromolar range, with a more marked selectivity as compared with the other two isoforms. These last two analyses have allowed us to understand why probe 10 shows the same affinity $\left(K_{d}\right)$ towards the three isoenzymes: it is a substrate for the ALDH1A1 and ALDH1A2, while it is a potent competitive inhibitor for the isoform $1 \mathrm{~A} 3$.

As show in Figure $3 \mathrm{~B}$, also probe 11 interacted with other two isoforms with a lower fluorescent signal, about 4 folds for ALDH1A1 and 6 folds for ALDH1A2, showing a strong selectivity versus ALDH1A3. Both molecules were tested with a serial dilution of pure recombinant ALDH1A1, ALDH1A2 and ALDH1A3, starting from a concentration of $100 \mu \mathrm{M}$ to evaluate the $K_{d}$ of the 
complexes, to better characterize the specific affinity of all these protein-probe complexes. Probe 11 preferentially interacts with ALDH1A1 and ALDH1A3, with similar $K_{d}$ values, while it appears to be slightly less affine in complex with the $1 \mathrm{~A} 2$ isoform. These data suggest that this molecule does not display a strong selectivity among the three enzymes, yet it behaves like a pan-probe for the ALDH1A subfamily (Figures $3 \mathrm{C}$ and 3D).

Taken together, these results suggest that both compounds are suitable for our aim from a biochemical perspective. Yet, a much deeper in vitro analysis is needed to confirm the potential selectivity of probe 10 and probe 11 and to better investigate the possible cytotoxic effects.

\section{ALDH1A3 detection in vitro}

To better characterized the selectivity fluorescence profile of probe 10 and 11, we selected four cell lines on the basis of their different ALDH1As expression profile, as described in The Human Protein Atlas (https://www.proteinatlas.org/), in order to validate the in vitro behaviour of the two probes. Human U87MG glioblastoma cells are labelled as $\mathrm{ALDH}_{1} \mathrm{~A}^{+}$cell line, HEK293T as ALDH1A2 ${ }^{+}$ cell line, human foetal astrocytes (hASTRO) as ALDH1A1+ cell line and 4T1 mammary carcinoma as triple negative ALDH1As subfamily ${ }^{22}$. We determined the ability of probe $\mathbf{1 0}$ and $\mathbf{1 1}$ to enter the cells and verified their fluorescence in ALDH1A3 positive cells. As depicted in Figures 4A and 4A, both probe 10 and probe 11 can determine fluorescence in U87MG cell line, but not in HEK293T, hASTRO and 4T1 cell lines. At the same time, both probe 10 and probe 11 are unable to induce cell mortality (Figures $4 \mathrm{~B}$ and $5 \mathrm{~B}$ ). The presence of the probes is localized into a cytosolic compartment that confirms the specific and exclusively cytosolic binding to ALDH1A3, as confirmed with fluorescence quantification (Figure $4 \mathrm{C}$ and $5 \mathrm{C}$ ). These data were corroborated by the flow cytometry analysis (Supplementary Figure S1), that highlighted the probe 10 and probe 11 ability to 
determine positivity in ALDH1A3 ${ }^{+}$cells (Figure 4D and 5D), positivity woke with DEAB pre-treatment, the pan-ALDH inhibitor.

\section{Probe 10 is able to selectively define glioblastoma cells in vivo}

Before evaluating the fluorescent signal of both probes in an in vivo model of orthotopic transplantation of murine glioblastoma cells GL261, an ALDH1A3 positive murine high-grade glioma cell line (Figure $6 \mathrm{~A}$ ), so as to select the most promising compound, we controlled if GL261 cells show the same permeability to our fluorescent compounds. Figure 6B shows that also in GL261 cells both probes 10 and 11 were able to enter and label the murine glioblastoma cells. In particular, probe 11 displays a higher intrinsic fluorescence, but it is less selective due to the presence of background signals that are non-specific for cancer cells internalization, as already suggested by the biochemical and the in vitro experiments. Nevertheless, even if the fluorescent signal has turned out to be lower in vitro, probe $\mathbf{1 0}$ appears to be more promising, due to its ability to accumulate only eminently within the tumour cells, with negligible accumulation in large neurons of the host and no accumulation in other cells of the mouse CNS. We induced glioblastoma in mice brain by stereotactically injecting $1 \times 10^{5} \mathrm{GL} 261$ cells into the left striatum of adult mice. All mice were injected i.p. with an equivalent dose of the 2 probes. The in vivo experiments showed that only the administration of probe $\mathbf{1 0}$ was able to selectively label the growing tumour. As shown in Figure 7, probe 10 accumulates in GL261 cells outlining the tumour growing in the left striatum and invading the adjacent areas of the brain, without significant interference from the adjacent tissue. Scattered tumour cells were also visualized infiltrating the adjacent areas of the mouse brain.

\section{Discussion}

The research of new targets for anti-cancer therapies and of markers for an efficient surgery and diagnosis still represents an ongoing challenge for 
several tumours, such as glioblastoma. Whit this paper, we describe new possible selective probes that are able to detect ALDH1A3 in HGG cancer cells. Both fluorescent compounds showed biological interesting data, suggesting the development of ALDH1As pan-probes with probe 10 as a starting point. Indeed, it can be considered as the first selective fluorescent probe for hALDH1A3 ever, which has been characterized and optimized for the target in our specific cancer cell line. The biochemical characterization of probe 10 suggests its selectivity towards ALDH1A3, and our in vitro experiments confirmed a strong signal only in U87 cell line, ALDH1A3 ${ }^{+}$, compared with our negative controls, that do not show any significant emission. The in vitro imaging using the 4T1 cell line, ALDH1A', shows non-unspecific signals. Moreover, the emission is only present in the cytosol, while the nucleus appeared to be free from any possible cross-reaction, as confirmed by DAPI staining. Probe $\mathbf{1 0}$ is characterized by benzaldehyde on the lateral chain in the same way as $D E A B$, as reported in literature ${ }^{47}$. This could be either a natural inhibitor or a substrate for a wide range of ALDHs. By taking advantage of this characteristic, probe 10 showed a marked binding preference for ALDH1As, even with identic $K_{D}$ values. As a matter of fact, this molecule is rapidly metabolized by ALDH1A1 and 1A2, but not from ALDH1A3. Indeed, we tested probe 10 as a potential competitive inhibitor and we observed a strong competitive inhibition only in the ALDH1A3 activity, with a low micromolar range of $K_{i}$ values. As confirmed by the in vitro imaging, probe 10 was detectable only in our positive controls U87MG and GL261 glioblastoma cell lines, whereas in the negative controls we were not able to detect any significant cytosolic emission. As a result, the probe 10 displays the characteristics of a false substrate of ALDH1A3 that most probably directly interact with the catalytic cysteine with an extremely slow rate, while the other two isoenzymes metabolize the molecule in a faster way. We also performed a flow cytometry analysis that showed that probe 10 is more selective than probe 11 on the U87 ALDH1A3 ${ }^{+}$cells, even with a lower fluorescent intensity. The in vivo experiments confirmed these data, given that we obtained a significant signal delimited to the tumour tissue in treated animals. 
Only a low fluorescent level was detectable in the healthy control. This property could be exploited to improve precision in fluorescence-guided resection of malignant gliomas. This is a rapidly evolving technique that is currently based on the injection of fluorescent markers like fluorescein and 5-aminolevulinic acid that accumulate in the tumour by unspecific mechanisms ${ }^{48-50}$.

The finding of new markers, with the aim of designing more specific molecules for more effective therapies and faster diagnosis, is essential for the modern precision medicine. ALDH1A3 represents one of the most suitable candidates for this goal. Taken together, our results highlight that probe $\mathbf{1 0}$ is a promising tool to selectively sort glioblastoma infiltrating cells, if compared with the probes already available on the market, such as ALDEFLOUR. Taken together, our results demonstrate that probe $\mathbf{1 0}$ is the first ALDH1A3 selective tool ever that is able to preferentially bind to the target enzyme, without inducing significant cytotoxic effects, both in vitro in Glioblastoma cells U87, and in GL261 cells outlining the tumour growing in the left striatum and invading the adjacent areas of the brain in vivo.

\section{Materials and Methods}

General: NMR spectra were measured on Bruker Avance $400 \mathrm{MHz}$ spectrometer or on a Bruker Avance $500 \mathrm{MHz}$. Chemical shifts were referenced to the residual solvent signal $\left(\mathrm{CDCl}_{3}: \delta_{\mathrm{H}}=7.21, \delta_{\mathrm{C}}=77.0\right)$. Reactions were monitored by thinlayer chromatography (TLC) on Merck 60 F254 $(0.25 \mathrm{~mm})$ plates, visualized by staining with $5 \% \mathrm{H}_{2} \mathrm{SO}_{4}$ in $\mathrm{EtOH}$ and heating. Organic phases were dried with $\mathrm{Na}_{2} \mathrm{SO}_{4}$ before evaporation. Chemical reagents and solvents were purchased from Sigma-Aldrich, TCI Europe or Fluorochem and were used without further purification unless stated otherwise. Petroleum ether with boiling point of 40-60 ${ }^{\circ} \mathrm{C}$ was used. Silica gel 60 (70-230 mesh) was used for gravity column chromatography (GCC). 
3-methoxy-4- propargyloxybenzaldehyde (2): propargyl bromide $(6.01 \mathrm{~mL}$, $80 \% \mathrm{w} / \mathrm{v}$ in toluene, $52.580 \mathrm{mmol}, 2 \mathrm{eq}$ ) was added to a suspension of vanillin (1, $4 \mathrm{~g}, 26.290 \mathrm{mmol}, 1 \mathrm{eq}$ ) and potassium carbonate (5.09 g, $36.806 \mathrm{mmol}, 1.4 \mathrm{eq}$ ) in acetone $(80 \mathrm{~mL})$. The suspension was heated to reflux for $12 \mathrm{~h}$ and the solvent was removed under reduced pressure. Water was added and the aqueous phase was extracted with EtOAc, washed with water, brine and dried. The crude was purified by column chromatography (PE/EtOAc 9:1 as eluent) to give 3-methoxy4- propargyloxybenzaldehyde $(2,2.58 \mathrm{~g}, 52 \%)$ as white crystalline solid. ${ }^{1} \mathrm{H}$ NMR $\left(400 \mathrm{MHz}, \mathrm{CDCl}_{3}\right) \delta\left(400 \mathrm{MHz}, \mathrm{CDCl}_{3}\right) 9.87(\mathrm{~s}, 1 \mathrm{H}), 7.47\left(\mathrm{dd}, J_{1}=6.8, J_{2}=1.4\right.$ $\mathrm{Hz}, 1 \mathrm{H}), 7.44(\mathrm{~d}, J=1.4 \mathrm{~Hz}, 1 \mathrm{H}), 7.14(\mathrm{~d}, J=6.8 \mathrm{~Hz}, 1 \mathrm{H}), 4.86(\mathrm{~d}, J=2.5 \mathrm{~Hz}$, $2 \mathrm{H}), 3.95(\mathrm{~s}, 3 \mathrm{H}), 2.56(\mathrm{t}, J=2.5 \mathrm{~Hz}, 1 \mathrm{H}) .{ }^{13} \mathrm{C} \mathrm{NMR}\left(100 \mathrm{MHz}, \mathrm{CDCl}_{3}\right) \delta$ 190.9, $152.1,150.0,130.9,126.3,112.5,109.4,77.4,77.2,56.6,56.0$.

(E)-6-(4-hydroxy-3-methoxyphenyl)hex-5-ene-2,4-dione (3): boron oxide (14.6 g, $174.85 \mathrm{mmol}, 5.3 \mathrm{eq})$ and acetyl acetone $(13,5 \mathrm{~mL}, 131.46 \mathrm{mmol}, 4 \mathrm{eq})$ were dissolved in DMF $(10 \mathrm{~mL})$ stirred at $80{ }^{\circ} \mathrm{C}$ for 1 hour. The mixture was cooled to $0{ }^{\circ} \mathrm{C}$, then trimethyl borate $(23,8 \mathrm{~mL}, 209.55 \mathrm{mmol}, 6.38 \mathrm{eq})$ and vanillin $(1,5 \mathrm{~g}$, $32.86 \mathrm{mmol}, 1 \mathrm{eq})$ were added. Butylamine $(1.3 \mathrm{~mL}, 13.27 \mathrm{mmol}, 0.4 \mathrm{eq})$ was then added dropwise. The obtained mixture was heated to $80{ }^{\circ} \mathrm{C}$ for 24 hours, then cooled to room temperature and $5 \% \mathrm{AcOH}_{\mathrm{aq}}(200 \mathrm{~mL})$ was added. The suspension was then stirred for 2 hours at room temperature and a yellow precipitate formed. The precipitate was filtered, washed with water $(3 \times 100 \mathrm{~mL})$, and purified by chromatography over silica (PE/EtOAc 7:3) to afford (E)-6-(4hydroxy-3-methoxyphenyl)hex-5-ene-2,4-dione $(3,3.22 \mathrm{~g}, 51 \%)$ as a yellow solid. ${ }^{1} \mathrm{H} \mathrm{NMR}\left(400 \mathrm{MHz}, \mathrm{CDCl}_{3}\right) \delta\left(400 \mathrm{MHz}, \mathrm{CDCl}_{3}\right) 7.53(1 \mathrm{H}, \mathrm{d}, \mathrm{J}=15.8 \mathrm{~Hz}, 1 \mathrm{H}), 7.09$ $(1 \mathrm{H}, \mathrm{dd}, J=8.2 \mathrm{~Hz}, J=1.9 \mathrm{~Hz}, 1 \mathrm{H}), 7.02(\mathrm{~d}, J=1.9 \mathrm{~Hz}, 1 \mathrm{H}), 6.92(\mathrm{~d}, J=8.2 \mathrm{~Hz}$, $1 \mathrm{H}), 6.32(\mathrm{~d}, J=15.8 \mathrm{~Hz}, 1 \mathrm{H}), 5.91(1 \mathrm{H}, \mathrm{bs}, \mathrm{OH}), 5.62(\mathrm{~s}, 1 \mathrm{H}), 3.94(\mathrm{~s}, 3 \mathrm{H}), 2.16$ (s, 3H). ${ }^{13} \mathrm{C}$ NMR $\left(100 \mathrm{MHz}, \mathrm{CDCl}_{3}\right) \delta 197.0,177.9,147.7,146.7,140.0,127.6$, 122.6, 120.2, 114.8, 109.5, 100.7, 55.9, 26.5.

(1E,4Z,6E)-5-hydroxy-1-(4-hydroxy-3-methoxyphenyl)-7-(3-methoxy-4-

(prop-2-yn-1-yloxy)phenyl)hepta-1,4,6-trien-3-one (4): boron oxide (142 mg, 
$1.708 \mathrm{mmol}, 0.4 \mathrm{eq}$ ) and 3 ( $1 \mathrm{~g}, 4.269 \mathrm{mmol}, 1 \mathrm{eq})$ were dissolved in DMF (2 mL) stirred at $80^{\circ} \mathrm{C}$ for 1 hour. The mixture was cooled to $0{ }^{\circ} \mathrm{C}$, then trimethyl borate $(810 \mathrm{~mL}, 7.129 \mathrm{mmol}, 1.67 \mathrm{eq})$ and 2 (893 mg, $4.696 \mathrm{mmol}, 1.1 \mathrm{eq})$ were added. Butylamine $(7 \mathrm{~mL}, 0.071 \mathrm{mmol}, 0.17 \mathrm{eq})$ was then added dropwise. The obtained mixture was heated to $80{ }^{\circ} \mathrm{C}$ for 24 hours, then cooled to room temperature and $5 \% \mathrm{AcOH}_{\mathrm{aq}}(50 \mathrm{~mL})$ was added. The suspension was then stirred for 2 hours at room temperature and an orange precipitate formed. The precipitate was filtered, washed with water $(3 \times 100 \mathrm{~mL})$, and purified by chromatography over silica (PE/EtOAc 6:4) to afford (1E,4Z,6E)-5-hydroxy-1-(4-hydroxy-3-methoxyphenyl)7-(3-methoxy-4-(prop-2-yn-1-yloxy)phenyl)hepta-1,4,6-trien-3-one $(4,1.21 \mathrm{~g}$, $72 \%)$ as an orange solid. ${ }^{1} \mathrm{H}$ NMR $\left(400 \mathrm{MHz}, \mathrm{CDCl}_{3}\right) \delta 7.59(\mathrm{~d}, J=15.7 \mathrm{~Hz}, 2 \mathrm{H})$, 7.08-7.12 (m, 3H), $7.04(\mathrm{~s}, 2 \mathrm{H}), 6.92(\mathrm{~d}, J=8.2 \mathrm{~Hz}, 1 \mathrm{H}), 6.45-6.51(\mathrm{~m}, 2 \mathrm{H}), 5.81$ (s, 1H), 4.79 (d, J = 2.3 Hz, 2H), $3.92(\mathrm{~d}, J=6.2 \mathrm{~Hz}, 6 \mathrm{H}$ ), $2.53(\mathrm{t}, J=4.84,3 \mathrm{H}$ ).

1-(4-(Dimethylamino)phenyl)-5-hydroxyhexa-1,4-dien-3-one (6): boron oxide $(4.17 \mathrm{~g}, 46.933 \mathrm{mmol}, 0.4 \mathrm{eq})$ and $5(1 \mathrm{~g}, 6.705 \mathrm{mmol}, 1 \mathrm{eq})$ were dissolved in EtOAc $(50 \mathrm{~mL})$ stirred at $80{ }^{\circ} \mathrm{C}$ for 1 hour. The mixture was cooled to $0{ }^{\circ} \mathrm{C}$, then trimethyl borate $(761 \mathrm{~mL}, 6.705 \mathrm{mmol}, 1 \mathrm{eq})$ and acetylacetone $(6.88 \mathrm{~mL}$, $67.047 \mathrm{mmol}, 10 \mathrm{eq})$ were added. Butylamine $(665 \mathrm{~mL}, 6.705 \mathrm{mmol}, 1 \mathrm{eq})$ was then added dropwise. The obtained mixture was heated to $80{ }^{\circ} \mathrm{C}$ for 72 hours, then cooled to room temperature. $\mathrm{H}_{2} \mathrm{SO}_{4} 2 \mathrm{M}(50 \mathrm{~mL})$ was added, then the organic phase was washed with $\mathrm{NaHCO}_{3}$ s.s. $(50 \mathrm{~mL})$, water, brine and dried. The crude was purified by column chromatography (PE/EtOAc 9:1 as eluent) to afford 1-(4(Dimethylamino)phenyl)-5-hydroxyhexa-1,4-dien-3-one (6, $291 \mathrm{mg}, 19 \%$ yield) as a red powder. ${ }^{1} \mathrm{H}$ NMR $\left(400 \mathrm{MHz}, \mathrm{CDCl}_{3}\right) \delta 7.38(\mathrm{~s}, 1 \mathrm{H}), 7.30(\mathrm{~d}, \mathrm{~J}=9.3 \mathrm{~Hz}, 2 \mathrm{H})$, $6.64(\mathrm{~d}, \mathrm{~J}=9.3 \mathrm{~Hz}, 2 \mathrm{H}), 3.04(\mathrm{~s}, 6 \mathrm{H}), 1.90(\mathrm{~d}, \mathrm{~J}=5.7 \mathrm{~Hz}, 6 \mathrm{H})$.

(1E,4Z,6E)-1-(4-(dimethylamino)phenyl)-5-hydroxy-7-(3-methoxy-4-(prop-2yn-1-yloxy)phenyl)hepta-1,4,6-trien-3-one (7): boron oxide (17 mg, 0.223 $\mathrm{mmol}, 0.4 \mathrm{eq}$ ) and 6 (130 mg, $0.558 \mathrm{mmol}, 1 \mathrm{eq})$ were dissolved in EtOAc ( $3 \mathrm{~mL})$ stirred at $80{ }^{\circ} \mathrm{C}$ for 1 hour. The mixture was cooled to $0{ }^{\circ} \mathrm{C}$, then trimethyl borate (191 mL, $0.949 \mathrm{mmol}, 1.67 \mathrm{eq})$ and 2 (106, $0.558 \mathrm{mmol}, 1 \mathrm{eq})$ were added. 
Butylamine ( $9 \mathrm{~mL}, 0.095 \mathrm{mmol}, 0.17 \mathrm{eq})$ was then added dropwise. The obtained mixture was heated to $80{ }^{\circ} \mathrm{C}$ for 24 hours, then cooled to room temperature. $\mathrm{H}_{2} \mathrm{SO}_{4} 2 \mathrm{M}(50 \mathrm{~mL})$ was added, then the organic phase was washed with water, brine and dried. The crude was purified by column chromatography (PE/EtOAc 7:3 as eluent) to afford (1E,4Z,6E)-1-(4-(dimethylamino)phenyl)-5-hydroxy-7-(3methoxy-4-(prop-2-yn-1-yloxy)phenyl)hepta-1,4,6-trien-3-one (7, 70 mg, 19\% yield) as a red powder. ${ }^{1} \mathrm{H}$ NMR $\left(300 \mathrm{MHz}, \mathrm{CDCl}_{3}\right) \delta 7.63(\mathrm{~d}, J=15.8 \mathrm{~Hz}, 1 \mathrm{H})$, 7.57 (d, $J=15.8 \mathrm{~Hz}, 1 \mathrm{H}), 7.46$ (d, J = 8.9 Hz, 2H), $7.08(\mathrm{~m}, 3 \mathrm{H}), 6.69$ (d, J = 8.6 $\mathrm{Hz}, 2 \mathrm{H}), 6.50(\mathrm{~d}, J=15.8 \mathrm{~Hz}, 1 \mathrm{H}), 6.43(\mathrm{~d}, J=15.8 \mathrm{~Hz}, 1 \mathrm{H}), 5.78(\mathrm{~s}, 1 \mathrm{H}), 4.80$ (d, $J=2.4 \mathrm{~Hz}, 2 \mathrm{H}), 3.92(\mathrm{~s}, 3 \mathrm{H}), 3.03(\mathrm{~s}, 6 \mathrm{H}), 2.53(\mathrm{t}, J=2.3 \mathrm{~Hz}, 1 \mathrm{H})$.

4-(2-Hydroxyethoxy)benzaldehyde (9): to a stirred solution of 4hydroxybenzaldehyde $(8,1 \mathrm{~g}, 8.188 \mathrm{mmol}, 1 \mathrm{eq})$ in DMF $(10 \mathrm{~mL}) \mathrm{K}_{2} \mathrm{CO}_{3}(2.26 \mathrm{~g}$, $16.376 \mathrm{mmol}, 2 \mathrm{eq})$ and 2-bromoethanol (1.16 $\mathrm{mL}, 16.376 \mathrm{mmol}, 2 \mathrm{eq})$ were added. The reaction was heated at $90{ }^{\circ} \mathrm{C}$ for 48 hours, then cooled to room temperature. $\mathrm{H}_{2} \mathrm{SO}_{4} 2 \mathrm{M}(20 \mathrm{~mL})$ was added, then the mixture was extracted with $\mathrm{PE} / \mathrm{Et}_{2} \mathrm{O} 3: 1(50 \mathrm{~mL})$ and the organic phase was washed with water, brine and dried. The crude was purified by column chromatography (PE/EtOAc 5:5 as eluent) to afford 4-(2-Hydroxyethoxy)benzaldehyde $(9,1.36 \mathrm{~g}, 100 \%)$ as a colorless oil. ${ }^{1} \mathrm{H}$ NMR (400 MHz, $\left.\mathrm{CDCl}_{3}\right) \delta 9.90(\mathrm{~s}, 1 \mathrm{H}), 7.85(\mathrm{~d}, \mathrm{~J}=9.3 \mathrm{~Hz}, 2 \mathrm{H})$, $7.03(\mathrm{~d}, J=8.7 \mathrm{~Hz}, 2 \mathrm{H}), 4.18(\mathrm{t}, J=9.0 \mathrm{~Hz}, 2 \mathrm{H}), 4.02(\mathrm{q}, J=9.3 \mathrm{~Hz}, 2 \mathrm{H})$.

4-(2-Azidoethoxy)benzaldehyde (10): to a stirred solution of 9 (680 mg, 4.094 $\mathrm{mmol}, 1 \mathrm{eq})$ in DCM $(10 \mathrm{~mL})$, TEA $(628 \mathrm{~mL}, 4.503 \mathrm{mmol}, 1.1 \mathrm{eq})$ and methansulfonyl chloride ( $350 \mathrm{~mL}, 4.503 \mathrm{mmol}, 1.1 \mathrm{eq}$ ) were added. The reaction was left at room temperature for 12 hours, then quenched with $\mathrm{H}_{2} \mathrm{SO}_{4} 2 \mathrm{M}$ (20 $\mathrm{mL})$. The organic phase was then washed with water, brine and dried. The crude was dissolved in DMF (10 mL), then sodium azide (798 $\mathrm{mg}, 12.382 \mathrm{mmol}, 3 \mathrm{eq}$ ) and a catalytic amount of $\mathrm{Nal}$ were added. The reaction was heated at $65^{\circ} \mathrm{C}$ for 12 hours, then quenched with brine. The organic phase was dried, and the crude was purified by column chromatography (PE/EtOAc 5:5 as eluent) to afford 4-(2Azidoethoxy)benzaldehyde $(10,712 \mathrm{mg}, 91 \%)$ as a yellow oil. ${ }^{1} \mathrm{H} \mathrm{NMR}(400 \mathrm{MHz}$, 
$\left.\mathrm{CDCl}_{3}\right) \delta=3.66(\mathrm{t}, J=4.9 \mathrm{~Hz}, 2 \mathrm{H}), 4.23(\mathrm{t}, J=4.9 \mathrm{~Hz}, 2 \mathrm{H}), 7.04(\mathrm{~d}, J=8.8 \mathrm{~Hz}$, $2 \mathrm{H}), 7.85(\mathrm{~d}, J=8.8 \mathrm{~Hz}, 2 \mathrm{H}), 9.91(\mathrm{~s}, 1 \mathrm{H}) .{ }^{13} \mathrm{C} \mathrm{NMR}\left(100 \mathrm{MHz}, \mathrm{CDCl}_{3}\right) \delta=50.0$, $67.2,114.8,130.5,132.0,163.1,190.7$.

Ethyl 2-azidoacetate (12): to a stirred solution of ethyl 2-bromoacetate (11, 1 $\mathrm{mL}, 9.017 \mathrm{mmol}, 1 \mathrm{eq})$ in DMF (10 mL), sodium azide $(1.759 \mathrm{mg}, 27.052 \mathrm{mmol}$, 3 eq) was added. The reaction was heated at $90{ }^{\circ} \mathrm{C}$ for 12 hours, then quenched with brine and extracted with PE. The organic phase was dried, and concentration of the solvent under reduced pressure gave ethyl 2-azidoacetate $(12,1.16 \mathrm{~g}$, $100 \%)$ as a colorless oil. ${ }^{1} \mathrm{H}$ NMR $\left(400 \mathrm{MHz}, \mathrm{CDCl}_{3}\right): \delta 4.15(\mathrm{q}, \mathrm{J}=6.8 \mathrm{~Hz}, 2 \mathrm{H})$, $3.77(\mathrm{~d}, J=1.2 \mathrm{~Hz}, 2 \mathrm{H}), 1.20\left(\mathrm{td}, J_{1}=7.2, J_{2}=1.2 \mathrm{~Hz}, 3 \mathrm{H}\right) .{ }^{13} \mathrm{C} \mathrm{NMR}(100 \mathrm{MHz}$, $\left.\mathrm{CDCl}_{3}\right): \delta$ 168.1, 61.5, 50.0, 13.8 .

\section{General procedure for copper catalyzed 1,3-dipolar cycloaddition:} synthesis of probe 13 as example: to a stirred solution of $4(50 \mathrm{mg}, 0.123 \mathrm{mmol}$, 1 eq) in t-BuOH/ $/ \mathrm{H}_{2} \mathrm{O} / \mathrm{CH}_{3} \mathrm{CN}$ 2:1:1, 10 (56 mg, $\left.0.256 \mathrm{mmol}, 2 \mathrm{eq}\right)$ and a catalytic amount of $\mathrm{CuSO}_{4}$ and sodium ascorbate were added. The solution was stirred at room temperature for 24 hours, then diluted with brine and extracted with EtOAc. The organic phase was dried and evaporated, then the crude was purified by chromatography over silica gel (PE:EtOAc 3:7 as solvent) to afford 13 (32 mg, $30 \%$ ) as an orange solid. Probes 14 and 15 were obtained following the same protocol.

13: orange powder, $30 \% .{ }^{1} \mathrm{H}$ NMR $\left(400 \mathrm{MHz}, \mathrm{CDCl}_{3}\right) \delta=9.91(\mathrm{~s}, 1 \mathrm{H}), 7.87-7.83$ (m, 3H), 7.63 (d, J= 10.4 Hz, 1H), $7.59(\mathrm{~d}, J=10.4 \mathrm{~Hz}, 1 \mathrm{H}), 7.16-7.07(\mathrm{~m}, 4 \mathrm{H})$, 6.98-6.92 (m, 3H), $6.51\left(\mathrm{dd}, J_{1}=15.8 \mathrm{~Hz}, J_{2}=2.9 \mathrm{~Hz}, 2 \mathrm{H}\right), 5.84(\mathrm{~s}, 1 \mathrm{H}), 5.37(\mathrm{~s}$, $2 \mathrm{H}), 4.83(\mathrm{t}, J=4.7 \mathrm{~Hz}, 2 \mathrm{H}), 4.48(\mathrm{t}, J=4.7 \mathrm{~Hz}, 2 \mathrm{H}), 3.07(\mathrm{~s}, 3 \mathrm{H}), 2.55(\mathrm{~s}, 3 \mathrm{H}) .{ }^{13} \mathrm{C}$ NMR $\left(100 \mathrm{MHz}, \mathrm{CDCl}_{3}\right) \delta 190.6,183.6,182.7,162.5,149.6,149.3,147.9,146.8$, $144.0,140.7,140.0,132.0,130.8,128.9,127.6,124.3,122.9,122.5,122.1$, $121.7,114.8,114.7,113.7,110.4,109.6,101.3,66.4,62.8,55.9,49.7$.

14: brown powder, 33\%. ${ }^{1} \mathrm{H}$ NMR $\left(400 \mathrm{MHz}, \mathrm{CDCl}_{3}\right) \delta=7.83(\mathrm{~s}, 1 \mathrm{H}), 7.60$ (dd, $\left.J_{1}=15.7 \mathrm{~Hz}, J_{2}=4.5 \mathrm{~Hz}, 2 \mathrm{H}\right), 7.14-7.07(\mathrm{~m}, 4 \mathrm{H}), 6.95(\mathrm{~d}, J=8.2 \mathrm{~Hz}, 1 \mathrm{H}), 6.50$ (dd, $\left.J_{1}=15.7 \mathrm{~Hz}, J_{2}=2.8 \mathrm{~Hz}, 2 \mathrm{H}\right), 5.83(\mathrm{~s}, 1 \mathrm{H}), 5.38(\mathrm{~s}, 2 \mathrm{H}), 5,17(\mathrm{~s}, 2 \mathrm{H}), 4.28(\mathrm{q}, J=$ 
7.1, 2H), $3.69(\mathrm{~s}, 3 \mathrm{H}), 3.92(\mathrm{~s}, 3 \mathrm{H}), 1.31(\mathrm{t}, J=7.1 \mathrm{~Hz}, 3 \mathrm{H}) .{ }^{13} \mathrm{C} \mathrm{NMR}(100 \mathrm{MHz}$, $\left.\mathrm{CDCl}_{3}\right) \delta$ 183.6, 182.9, 166.0, 149.6, 149.4, 147.9, 146.8, 144.2, 140.7, 140.1, $128.9,127.6,124.5,124.5,122.9,122.4,122.3,121.7,114.8,113.8,110.5$, 109.6, 101.3, 62.8, 62.5, 55.9, 51.0, 14.0 .

15: red powder, $31 \% .{ }^{1} \mathrm{H}$ NMR $\left(400 \mathrm{MHz}, \mathrm{CDCl}_{3}\right) \delta=9.91(\mathrm{~s}, 1 \mathrm{H}), 7.84-7.86(\mathrm{~m}$, $2 \mathrm{H}), 7.67-7.58(\mathrm{~m}, 3 \mathrm{H}), 7.20-7.03(\mathrm{~m}, 3 \mathrm{H}), 6.97(\mathrm{~d}, J=8.7 \mathrm{~Hz}, 2 \mathrm{H}), 6.57(\mathrm{~d}, J=$ $15.8 \mathrm{~Hz}, 2 \mathrm{H}), 6.52(\mathrm{~d}, \mathrm{~J}=15.8 \mathrm{~Hz}, 2 \mathrm{H}), 5.85(\mathrm{~s}, 1 \mathrm{H}), 5.37(\mathrm{~s}, 1 \mathrm{H}), 4.83(\mathrm{t}, \mathrm{J}=4.9$ $\mathrm{Hz}, 2 \mathrm{H}), 4.48(\mathrm{t}, \mathrm{J}=4.9 \mathrm{~Hz}, 2 \mathrm{H}), 2.33(\mathrm{~s}, 3 \mathrm{H}), 4.24(\mathrm{~s}, 6 \mathrm{H}) .{ }^{13} \mathrm{C} \mathrm{NMR}(100 \mathrm{MHz}$, $\left.\mathrm{CDCl}_{3}\right) \delta^{13} \mathrm{C} \mathrm{NMR}\left(101 \mathrm{MHz}, \mathrm{CDCl}_{3}\right) \delta$ 190.6, 162.5, 149.6, 132.0, 130.8, 129.8, 124.2, 122.5, 114.7, 113.7, 110.4, 81.7, 66.4, 62.9, 56.0, 49.6, 29.7.

General procedure for diethylphosphate derivative: synthesis of probe 16 as example: to stirred solution of 13 (150 $\mathrm{mg}, 0.251 \mathrm{mmol}, 1 \mathrm{eq})$ in dry DCM (10 $\mathrm{mL}$ ), TEA (105 mL, $0.753 \mathrm{mmol}, 3 \mathrm{eq}$ ) and diethylchlorophosphate ( $54 \mathrm{~mL}, 0.377$ $\mathrm{mmol}, 1.5 \mathrm{eq}$ ) were added. The reaction was stirred at room temperature for 24 hours, then quenched with $\mathrm{H}_{2} \mathrm{SO}_{4} 2 \mathrm{M}$. The organic phase was then washed with brine and dried. The crude was purified by chromatography over silica (EtOAC as eluent) to afford probe 16 ( $47 \mathrm{mg}, 23 \%)$ as orange solid. Probe 17 was obtained following the same protocol.

16: orange solid, 23\%. ${ }^{1} \mathrm{H}$ NMR $\left(400 \mathrm{MHz}, \mathrm{CDCl}_{3}\right) \delta=9.90(\mathrm{~s}, 1 \mathrm{H}), 7.83-7.79(\mathrm{~m}$, $3 \mathrm{H}), 7.61(\mathrm{~d}, \mathrm{~J}=15.7 \mathrm{~Hz}, 2 \mathrm{H}), 7.35-6.95(\mathrm{~m}, 7 \mathrm{H}), 6.54(\mathrm{~m}, 2 \mathrm{H}), 5.86(\mathrm{~s}, 1 \mathrm{H}), 5.37$ (s, 2H), 4.83 (bt, 2H), 4.47 (bt, 2H), 4.30 (m, 4H) 3.95 (s, 3H), 3.93 (s, 3H), 1.39 (t, $J=6.89 \mathrm{~Hz}, 6 \mathrm{H}) .{ }^{13} \mathrm{C}$ NMR $\left(100 \mathrm{MHz}, \mathrm{CDCl}_{3}\right) \delta 190.6,183.9,182.3,162.5$, $150.9,150.9,149.6,149.4,143.9,141.3,140.5,139.5,132.8,132.0,130.7$, $128.8,124.3,124.0,122.5,122.3,121.6,121.1,114.7,113.7,111.7,110.5$, 101.6, 66.4, 64.7, 64.7, 62.8, 56.0, 49.7, 16.1, 16.0.

17: brown solid, 76\%. ${ }^{1} \mathrm{H}$ NMR (400 MHz, $\left.\mathrm{CDCl}_{3}\right) \delta 7.83(\mathrm{~s}, 1 \mathrm{H}), 7.61$ (d, J=6.7 $\mathrm{Hz}, 1 \mathrm{H}), 7.57(\mathrm{~d}, J=6.7 \mathrm{~Hz}, 1 \mathrm{H}), 7.32(\mathrm{~d}, J=7.9 \mathrm{~Hz}, 1 \mathrm{H}), 7.13-7.08(\mathrm{~m}, 4 \mathrm{H}), 6.57-$ $6.49(\mathrm{~m}, 2 \mathrm{H}), 5.85(\mathrm{~s}, 3 \mathrm{H}), 5.36(\mathrm{~s}, 2 \mathrm{H}), 5.16(\mathrm{~s}, 2 \mathrm{H}), 4.30-4.19(\mathrm{~m}, 6 \mathrm{H}), 3.92(\mathrm{~s}$, $3 \mathrm{H}), 3.91(\mathrm{~s}, 3 \mathrm{H}), 1.38(\mathrm{t}, \mathrm{J}=7.0 \mathrm{~Hz}, 3 \mathrm{H}) .1 .30(\mathrm{t}, \mathrm{J}=7.0 \mathrm{~Hz}, 3 \mathrm{H}) .{ }^{13} \mathrm{C}$ NMR $(100$ $\left.\mathrm{MHz}, \mathrm{CDCl}_{3}\right) \delta 184.0,182.2,166.0,150.8,149.7,149.5,144.1,141.3,140.6$, 
$139.4,132.8,128.7,124.6,124.0,122.3,121.5,121.0,113.7,111.7,110.5$, $101.6,64.7,62.8,62.5,56.0,51.0,29.7,16.1,14.0$.

\section{Expression and Purification of the recombinant human aldehyde dehydrogenases $1 \mathrm{~A}$ subfamily}

A common experimental protocol has been developed with the aim of obtaining pure human $A L D H 1 A 1,1 A 2$ and $1 \mathrm{~A} 3$ at a high yield, as already described ${ }^{22}$. Briefly, E. coli BL21 (DE3) were transformed with the full-length expression vector of each isoform and seeded onto 2xTY agar plates containing $50 \mu \mathrm{g} / \mathrm{mL}$ ampicillin for ALDH1A1 and ALDH1A3 subtypes, and $50 \mu \mathrm{g} / \mathrm{mL}$ kanamycin for ALDH1A2. Petri plates were incubated for the overnight growth at $37^{\circ} \mathrm{C}$. The following day, colonies were scraped and used to inoculate $1 \mathrm{~L}$ of 2xTY liquid medium, which was previously added with $50 \mu \mathrm{g} / \mathrm{mL}$ ampicillin for ALDH1A1 and ALDH1A3, and $50 \mu \mathrm{g} / \mathrm{mL}$ kanamycin for ALDH1A2. Flasks were put under shaking at $37{ }^{\circ} \mathrm{C}$ and, once $\mathrm{OD}_{600}=0.6-0.8$ was reached, the temperature was shifted to $20^{\circ} \mathrm{C}$ to induce the recombinant protein production. The induced cells were collected by centrifugation and stored at $-80{ }^{\circ} \mathrm{C}$. The harvested pellet was thawed and resuspended in lysis buffer (50 mM Na2HPO4, $300 \mathrm{mM} \mathrm{NaCl}, 1 \mathrm{mM} \beta$-mercaptoethanol, $20 \mathrm{mM}$ imidazole, $\mathrm{pH}$ 7.5) with $1 \mu \mathrm{L}$ per $80 \mathrm{~mL}$ of lysis buffer of benzonase nuclease (250 U/ $\mu \mathrm{L}$ ). E. coli BL21 (DE3) cells were disrupted using a French Press system, three times at $1.5 \mathrm{Kbar}$, adding 100 $\mu \mathrm{L}$ per $40 \mathrm{~mL}$ of lysis buffer of a Protease inhibitor cocktail from SIGMA. To obtain the clarified cell lysate, the cell debris was removed by centrifugation at 18.000 rpm for $50 \mathrm{~min}$. The recombinant proteins were purified by a His-tag affinity chromatography followed by size-exclusion chromatography, using an AKTA FPLC system at $4{ }^{\circ} \mathrm{C}$. To better evaluate the purity and homogeneity of the protein after each purification step, eluted fractions were analysed by SDS-PAGE. The final protein concentration was determined through the Bradford protein assay. In the first purification step, the collected supernatant was loaded on a Qiagen NiNTA Superflow $5 \mathrm{~mL}$ cartridge that was previously equilibrated with 10 column 
volumes of lysis buffer. The Ni-NTA cartridge was washed with 15 column volumes of $50 \mathrm{mM} \mathrm{Na} 2 \mathrm{HPO}$, $300 \mathrm{mM} \mathrm{NaCl}, 1 \mathrm{mM} \beta$-mercaptoethanol, $50 \mathrm{mM}$ imidazole, $\mathrm{pH} 7.5$, until the absorbance at $280 \mathrm{~nm}$ returned to the baseline. The recombinant hALDH1A was eluted with $50 \mathrm{mM} \mathrm{Na} 2 \mathrm{HPO} 4,300 \mathrm{mM} \mathrm{NaCl}, 1 \mathrm{mM}$ $\beta$-mercaptoethanol, $250 \mathrm{mM}$ imidazole, $\mathrm{pH}$ 8, by applying a linear gradient in 10 column volumes. Eluted fractions were pooled and concentrated to $5 \mathrm{~mL}$ with Merck Millipore Amicon Ultra-15 $30 \mathrm{kDa}$ and loaded on a HiLoad 16/600 Superdex $200 \mathrm{pg}$ column on AKTA FPLC system. Elution buffer contained $20 \mathrm{mM}$ Tris $\mathrm{HCl} \mathrm{pH} 8.0,150 \mathrm{mM} \mathrm{KCl}, 1 \mathrm{mM} \beta$-mercaptoethanol, and a flow rate of 1 $\mathrm{mL} / \mathrm{min}$ was applied. By means of this procedure, $20 \mathrm{mg}$ of pure and active human ALDH1A1, ALDH1A2 and ALDH1A3 were obtained, stocked at $-80^{\circ}$ and later used for biochemical analysis.

\section{Absorbance, emission and excitation wavelengths evaluation}

Fluorescent compounds were analysed on a Tecan Spark to evaluate the correct parameters to further set the biochemical characterizations. The absorbance was evaluated in a range from $300 \mathrm{~nm}$ to $700 \mathrm{~nm}$, with a wavelength step size of $5 \mathrm{~nm}$. Based on the absorbance values, we settled a 3D fluorescence emission scan to evaluate the excitation and emission peaks. The analysis was conducted using the same buffer mix, as already described. The excitation range was set between 390 and $450 \mathrm{~nm}$ for both molecules, with a step size of $5 \mathrm{~nm}$. The emission range was set between 485 and $700 \mathrm{~nm}$ for both molecules, with a step size of $5 \mathrm{~nm}$. All these characterizations were performed on a Tecan Spark using Greiner Bio-One 96-UV-Transparent Microplates and the tests were carried out using a total volume of $100 \mu \mathrm{L}$ for each well.

\section{Chemical stability and Cross reactions with biomolecules assay}

Based on the values obtained by the $3 D$ analysis, a wide series of biomolecules directly used in the biochemical experiment, both in vitro and in vivo, 
and listed in table 1, were tested in complex with a fixed concentration of $10 \mu \mathrm{M}$ of both probes, to measure any possible cross reaction signal.

\section{$K_{d}$ evaluation of the probes probe 14 and probe 13 in complex with human}

\section{ALDH1A isoforms}

To evaluate the $K_{d}$ constant between the two probes and the isoenzymes ALDH1A1, ALDH1A2 and ALDH1A3A we performed a fluorescence emission assay. We used a Tecan Spark with Greiner Bio-One 96-UV-Transparent Microplates. A single reaction was performed in a total volume of $100 \mu \mathrm{L}$ per well containing $20 \mathrm{mM}$ Tris $\mathrm{HCl}$ pH 8.0, $1 \mathrm{mM} \beta$-mercaptoethanol, $150 \mathrm{mM} \mathrm{KCl}, 500$ $\mu \mathrm{M} \mathrm{NAD}$ and $10 \mu \mathrm{M}$ fluorescent probe with a $5 \%$ DMSO final concentration, in the presence of different ALDH1As concentrations, from $100 \mu \mathrm{M}$ to $1,1719 \mu \mathrm{M}$. Each reaction mix was preincubated for $10 \mathrm{~min}$ at $25^{\circ} \mathrm{C}$ before the analysis. The obtained raw data were analysed using GraphPad to calculate $K_{d}$ values.

\section{$\mathrm{K}_{M}$ evaluation of probe 13 in complex with the human ALDH1As isoforms}

The catalytic activity of the ALDH1As isoenzymes in complex with probe 10 was tested on a Tecan Sunrise 96 Multiplate Reader with Greiner Bio-One 96UV-Transparent Microplates. The analysis was performed in triplicate in a total volume of $100 \mu \mathrm{L}$ per well containing $20 \mathrm{mM}$ Tris $\mathrm{HCl} \mathrm{pH} 8.0,1 \mathrm{mM} \beta$ mercaptoethanol, $150 \mathrm{mM} \mathrm{KCl}, 500 \mu \mathrm{M} \mathrm{NAD}^{+}, 1.41 \mu \mathrm{M}$ DMSO, $2.8 \mu \mathrm{M}$ hALDH1As and probe $\mathbf{1 0}$ was tested as substrate at different concentrations, from $300 \mu \mathrm{M}$ to $3.125 \mu \mathrm{M}$. Each reaction mix was preincubated for $10 \mathrm{~min}$ at $25^{\circ} \mathrm{C}$ before the analysis. The catalytic activity was measured by monitoring the absorbance at $340 \mathrm{~nm}(\varepsilon \mathrm{NADH}=6220 \mathrm{M}-1 \mathrm{~cm}-1)$ for $12 \mathrm{~h}$ at $25^{\circ} \mathrm{C}$ and the inhibitory parameters were calculated by processing the raw data on GraphPad.

\section{$I_{50}$ and $K_{i}$ evaluation of probe 13 on the ALDH1A isoforms}

Initially, the inhibitory activities of our fluorescent probes were screened at a fixed concentration of $50 \mu \mathrm{M}$ using a Tecan Sunrise 96 Multiplate Reader with 
Greiner Bio-One 96-UV-Transparent Microplates. The analysis was performed in triplicate in a total volume of $100 \mu \mathrm{L}$ per well containing $20 \mathrm{mM}$ Tris $\mathrm{HCl} \mathrm{pH}$ 8.0, $1 \mathrm{mM} \beta$-mercaptoethanol, $150 \mathrm{mM} \mathrm{KCl}, 500 \mu \mathrm{M} \mathrm{NAD}^{+}, 1.41 \mu \mathrm{M}$ DMSO, $2.8 \mu \mathrm{M}$ hALDH1A and $20 \mathrm{mM}$ acetaldehyde. Afterwards, the inhibitory potency of the fluorescent probes was further investigated, evaluating the $\mathrm{IC}_{50}$ parameter. The enzymatic inhibition assays were performed in triplicate in a total volume of 100 $\mu \mathrm{L}$ per well containing $20 \mathrm{mM}$ Tris $\mathrm{HCl} \mathrm{pH} \mathrm{8.0,1} \mathrm{mM} \beta$-mercaptoethanol, $150 \mathrm{mM}$ $\mathrm{KCl}, 500 \mu \mathrm{M} \mathrm{NAD}^{+}, 2.8 \mu \mathrm{M} \mathrm{hALDH} 1 \mathrm{~A}$ and $20 \mathrm{mM}$ acetaldehyde in the presence of different probe concentrations, from $200 \mu \mathrm{M}$ to $1.5625 \mu \mathrm{M}$. The DMSO final concentration allowed was up to $15 \%$. Only for ALDH1A3 in complex with probe 13 , the $K_{i}$ affinity parameter was calculated by performing the analysis in triplicate in a total volume of $100 \mu \mathrm{L}$ per well containing $20 \mathrm{mM}$ Tris $\mathrm{HCl} \mathrm{pH} \mathrm{8.0,1} \mathrm{mM} \beta$ mercaptoethanol, $150 \mathrm{mM} \mathrm{KCl}, 500 \mu \mathrm{M} \mathrm{NAD}^{+}$and $2.8 \mu \mathrm{M}$ ALDH1As. Due to chemical nature of probe 10 and probe 11, we set up the enzymatic assay assuming a competitive inhibition using different compounds concentration, from $200 \mu \mathrm{M}$ to $1 \mu \mathrm{M}$, and different acetaldehyde concentrations, from $20 \mathrm{mM}$ to 2.5 $\mathrm{mM}$. Each reaction mix was preincubated for $10 \mathrm{~min}$ at $25^{\circ} \mathrm{C}$ before the analysis. The catalytic activity was measured by monitoring the absorbance at $340 \mathrm{~nm}$ ( $\varepsilon \mathrm{NADH}=6220 \mathrm{M}-1 \mathrm{~cm}-1$ ) for $30 \mathrm{~min}$ at $25^{\circ} \mathrm{C}$ and the inhibitory parameters were calculated by processing the raw data on SigmaPlot.

\section{Cell Culture}

U87MG human glioblastoma, and 4T1 murine mammary carcinoma cell lines were cultured in Minimum Essential Medium Eagle (MEM, Sigma-Aldrich). The HEK293T human embryonic kidney cell line and GL261 high grade glioma cells were cultured in Dulbecco's Modified Eagle's Medium (DMEM, SigmaAldrich). All these cell lines with the exception of GL261 were purchased from ATCC. Media were supplemented with $10 \%$ foetal bovine serum (FBS, Gibco), 2 $\mathrm{mg} / \mathrm{ml}$ glutamine, $10 \mathrm{U} / \mathrm{ml}$ penicillin and $100 \mathrm{~g} / \mathrm{ml}$ streptomycin (Sigma-Aldrich). Human foetal astrocytes were kindly provided by Eleonora Aronica's lab in 
Amsterdam and cultured in DMEM+F10 medium. Cells were maintained in a controlled atmosphere of $5 \% \mathrm{CO}_{2}$ with humidity at $37^{\circ} \mathrm{C}$. Cells were detached from plates by trypsin-EDTA (Sigma-Aldrich).

\section{Confocal microscopy}

20,000 cells/mL of U87MG, HEK293T, hASTRO and 4T1 were seeded onto glass cover slips in twenty-four-well plates. The cells incubated at $37^{\circ} \mathrm{C}$ in a $5 \% \mathrm{CO}_{2}$ atmosphere overnight. Cells were washed with $1 \mathrm{~mL}$ of PBS buffer two times, then a $10 \mu \mathrm{M}$ solution of probes was added to each well for $2 \mathrm{~h}$. The cover slips were removed and washed with PBS buffer, and fixed with $0.5 \mathrm{ml}$ of $4 \%$ formaldehyde solution for $10 \mathrm{~min}$. The cover slips were washed with $1 \mathrm{~mL}$ of PBS, then slides were prepared using Mounting Media (Merck Life Science). Fluorescence images were acquired using a Leica (Leica Microsystems, Wetzlar, Germany) epifluorescent microscope equipped with an S Fluor 40x/1.3 objective using the LAS $X$ software.

\section{Flow Cytometry}

U87MG, HEK293T, hASTRO and 4T1 cells were resuspended in PBS to a final concentration of $10^{6}$ cells $/ \mathrm{mL}$. Each sample was then resuspended in probe 10 and probe 11 solutions ( $1 \mu \mathrm{M}$, in ALDEFLUOR assay buffer, STEMCELL). Triplicate samples were prepared for each dye. Cells were pre-treated with DEAB for 15 minutes and then incubated with the probes for 30 minutes at room temperature, with rocking to prevent cell clumping and ensure an even dye distribution. At the end of the incubation period, cells were harvested by centrifugation at $1000 \mathrm{rpm}$ for $5 \mathrm{~min}$ at $4{ }^{\circ} \mathrm{C}$. The probe solutions were removed and each sample was resuspended in the ALDEFLUOR assay buffer. The samples were immediately placed in ice until analysis. The samples were analysed by a S3e Cell Sorter (BIO-RAD). 
GL261 cells were incubated, with probe 10 or 11, for 1 hour and after three rinses in PBS, cells were detached by trypsin treatment and visualized without fixation through a rMarkll flow cytometer (Amnis, Luminex Corporation, Austin, TX, USA) as previously described ${ }^{51}$. Data were collected using Inspire software (Amnis, version 2.0) with the following parameters: 10,000 images per sample, $488 \mathrm{~nm}$ laser ( $25 \mathrm{~mW}$ and $100 \mathrm{~mW}$ ) to excite the probes, $785 \mathrm{~nm}$ laser used to provide a side scatter signal and measurement of SpeedBeads (Amnis, Luminex Corporation, Austin, TX, USA), $830 \mathrm{~nm}$ laser used for internal bead calibration of core flow speed and focus, 60X objective, in low-speed flow. Data were further analyzed by Ideas software (Amnis, version 6.1).

\section{Cell viability}

$10 \times 10^{\wedge} 5$ U87MG human glioblastoma, HEK293T human embryonic kidney, 4T1 murine mammary carcinoma and human foetal astrocytes cell lines were plated in their respective medium and treated for 72 hours with our fluorescent probe $\mathbf{1 0}$ and $\mathbf{1 1}$, solubilized in DMSO in a final concentration of $10 \%$. The viability of cells was measured using the 3-(4,5-dimethylthiazol-2-yl)-2,5diphenyltetrazolium assay (MTT assay) ${ }^{22}$.

\section{Animal Experiments}

We used in vitro and in vivo cells from a mouse high grade glioma cell line, GL261 ${ }^{52}$. Briefly, 102 - to 3-month-old female C57BIC mice were stereotactically implanted under deep general anesthesia (isoflurane supplemented with nitrous oxide) with $1 \times 10^{5}$ GL261 glioblastoma cells. The cells were stereotactically inoculated through a burr hole by a Hamilton syringe into the left striatum (coordinates: $1 \mathrm{~mm}$ anteroposterior and $1 \mathrm{~mm}$ lateral from bregma, at a depth of $3 \mathrm{~mm}$ ). All experimental procedures were conducted in accordance with the European Communities Council Directive of the $24^{\text {th }}$ of November $1986(86 / 609$ EEC), with the Recommendation 18/06/2007, Dir. 2010/63/UE and with the Italian law for care and use of experimental animals (DL116/92) and were approved by 
the Italian Ministry of Health (prot. E669C.15) and by the Bioethical Committee of the University of Turin. All animals were housed under a 12-hour light-dark cycle in an environmentally controlled room. All experiments were designed to minimize the numbers of animals used and their discomfort. In each experiment, animals with tumours were allocated to two groups and i.p. injected with probe $\mathbf{1 0}$ or probe 11. All drugs were administered intraperitoneally, and treatments were started 6 days after tumour implantation. Animals were euthanized 6 days after the i.p injection. Briefly, they were transcardially perfused under deep anesthesia (ketamine 100 mg/mg, Ketavet, Bayern, Leverkusen, Germany; xylazine 5 mg/kg, Rompun, Bayern, Leverkusen, Germany) with 4\% paraformaldehyde in $0.12 \mathrm{M}$ phosphate buffer, $\mathrm{pH} 7.2$ to 7.4 . The brains were dissected and cut into $50 \mu \mathrm{m}$ thick cryostat coronal sections. Sections were incubated and counterstained with 4',6-diamidino-2- phenylindole (DAPI). After processing, sections were mounted on microscope slides with Tris-glycerol supplemented with 10\% Mowiol (Calbiochem). Quantitative and phenotypic evaluations were made on the images acquired with a Leica TCS SP5 confocal microscope. Fiji (http://fiji.sc/Image_Stitching), Inkscape (http://inkscape.org), and Photoshop CS6 (Adobe Inc. https://www.adobe.com) were used to assemble all figures.

\section{Acknowledgments and funding sources}

S.G., M.A. and D.M.F. acknowledges the University of Piemonte Orientale (grant Ricerca Ateneo FAR_2016 and FAR_2019) and ROCHE per la Ricerca 2017, for the financial support. M.L. was supported by Fondazione I.R.C.C.S. Policlinico S. Matteo Ricerca Corrente (codice ric. 08016019). S.G. and M.A. acknowledge Professor Fabrizio Condorelli for the stimulating scientific discussion regarding this paper. We acknowledge the HIS Mouse Facility of the Academic Medical Center, Amsterdam and the Bloemenhove Clinic (Heemstede, The Netherlands) for providing foetal 
tissues. We would also thank Dott. Alberto Azzalin for his help with rMarkll flow cytometer.

Author Contributions: E.L.M.G., D.C. and G.C. designed and performed all the experiments and wrote the manuscript.

D.C., D.M. and S.S. synthesized the fluorescent probe.

E.L.M.G. and D.M. purified the recombinant enzymes and performed all the biochemical evaluation experiments.

G.C. and M.L. performed all the experiment with the cancers cell lines and the flow cytometric studies.

E.A. contributed expertise and the human foetal astrocytes.

G.N., A.B and M.L. performed the in vivo experiments.

D.M.F., M.L. and M.R. provided funding, contributed expertise and revised the final version of the manuscript.

A.M. and S.G. provided funding, supervised and supervised all the experiment, wrote the manuscript.

\section{Conflicts of Interest:}

The authors declare no conflict of interest.

The authors state that the work reported in these papers led to a patent name: "SONDA DIRETTA ALL'ENZIMA ALDH1A3 E RELATIVO USO NELLA DIAGNOSI DI GLIOBLASTOMA";

number: 102021000008504;

geographical region: Italy; applicants: University of Piemonte Orientale $90 \%$; University of Pavia 10\%; inventors: Prof. Silvia Garavaglia, Prof. Alberto Minassi, Prof.Menico Rizzi, Dott. Edoardo L. M. Gelardi, Dott. Diego Caprioglio, Dott. Giorgia Colombo, Prof. Lorenzo Magrassi. 


\section{References:}

1. Bai, J., Varghese, J. \& Jain, R. Adult Glioma WHO Classification Update, Genomics, and Imaging: What the Radiologists Need to Know. Topics in Magnetic Resonance Imaging 29, 71-82 (2020).

2. Dunn, G. P. et al. Emerging insights into the molecular and cellular basis of glioblastoma. Genes \& Development 26, 756-784 (2012).

3. Batlle, E. \& Clevers, H. Cancer stem cells revisited. Nat Med 23, 1124-1134 (2017).

4. Chen, X., Liao, R., Li, D. \& Sun, J. Induced cancer stem cells generated by radiochemotherapy and their therapeutic implications. Oncotarget 8, 17301-17312 (2017).

5. Fedele, M., Cerchia, L., Pegoraro, S., Sgarra, R. \& Manfioletti, G. ProneuralMesenchymal Transition: Phenotypic Plasticity to Acquire Multitherapy Resistance in Glioblastoma. IJMS 20, 2746 (2019).

6. Behnan, J., Finocchiaro, G. \& Hanna, G. The landscape of the mesenchymal signature in brain tumours. Brain 142, 847-866 (2019).

7. Singh, S. K. et al. Identification of human brain tumour initiating cells. Nature 432, 396401 (2004).

8. Carro, M. S. et al. The transcriptional network for mesenchymal transformation of brain tumours. Nature 463, 318-325 (2010).

9. Mao, P. et al. Mesenchymal glioma stem cells are maintained by activated glycolytic metabolism involving aldehyde dehydrogenase 1A3. Proceedings of the National Academy of Sciences 110, 8644-8649 (2013).

10. Phillips, H. S. et al. Molecular subclasses of high-grade glioma predict prognosis, delineate a pattern of disease progression, and resemble stages in neurogenesis. Cancer Cell 9, 157-173 (2006).

11. Stupp, R. et al. Radiotherapy plus Concomitant and Adjuvant Temozolomide for Glioblastoma. N Engl J Med 352, 987-996 (2005).

12. Perry, J. R. et al. Short-Course Radiation plus Temozolomide in Elderly Patients with Glioblastoma. N Engl J Med 376, 1027-1037 (2017).

13. Zhang, W. et al. ALDH1A3: A Marker of Mesenchymal Phenotype in Gliomas Associated with Cell Invasion. PLoS One 10, e0142856 (2015).

14. Ferraris, D. M., Gelardi, E. L. M., Garavaglia, S., Miggiano, R. \& Rizzi, M. Targeting NAD-dependent dehydrogenases in drug discovery against infectious diseases and cancer. Biochem Soc Trans 48, 693-707 (2020).

15. Koppaka, V. et al. Aldehyde dehydrogenase inhibitors: a comprehensive review of the pharmacology, mechanism of action, substrate specificity, and clinical application. Pharmacol Rev 64, 520-539 (2012).

16. Marchitti, S. A., Brocker, C., Stagos, D. \& Vasiliou, V. Non-P450 aldehyde oxidizing enzymes: the aldehyde dehydrogenase superfamily. Expert Opin Drug Metab Toxicol 4, 697-720 (2008).

17. Moretti, A. et al. Crystal structure of human aldehyde dehydrogenase 1A3 complexed with NAD+ and retinoic acid. Sci Rep 6, 35710 (2016).

18. Duan, J.-J., Cai, J., Guo, Y.-F., Bian, X.-W. \& Yu, S.-C. ALDH1A3, a metabolic target for cancer diagnosis and therapy. Int J Cancer 139, 965-975 (2016).

19. Tomita, H., Tanaka, K., Tanaka, T. \& Hara, A. Aldehyde dehydrogenase $1 \mathrm{~A} 1$ in stem cells and cancer. Oncotarget 7, 11018-11032 (2016).

20. Nwani, N. et al. A Novel ALDH1A1 Inhibitor Targets Cells with Stem Cell Characteristics in Ovarian Cancer. Cancers 11, 502 (2019). 
21. Kharkar, P. S. Cancer Stem Cell (CSC) Inhibitors in Oncology-A Promise for a Better Therapeutic Outcome: State of the Art and Future Perspectives. J Med Chem 63, 15279-15307 (2020).

22. Gelardi, E. L. M. et al. A Selective Competitive Inhibitor of Aldehyde Dehydrogenase 1A3 Hinders Cancer Cell Growth, Invasiveness and Stemness In Vitro. Cancers 13, 356 (2021).

23. Cheng, P. et al. FOXD1-ALDH1A3 Signaling is a Determinant for the SelfRenewal and Tumorigenicity of Mesenchymal Glioma Stem Cells. Cancer Res 76, 7219-7230 (2016).

24. Clark, D. W. \& Palle, K. Aldehyde dehydrogenases in cancer stem cells: potential as therapeutic targets. Ann Transl Med 4, 518 (2016).

25. Januchowski, R., Wojtowicz, K. \& Zabel, M. The role of aldehyde dehydrogenase (ALDH) in cancer drug resistance. Biomed Pharmacother 67, 669-680 (2013).

26. Holohan, C., Van Schaeybroeck, S., Longley, D. B. \& Johnston, P. G. Cancer drug resistance: an evolving paradigm. Nat Rev Cancer 13, 714-726 (2013).

27. Januchowski, R. et al. Inhibition of ALDH1A1 activity decreases expression of drug transporters and reduces chemotherapy resistance in ovarian cancer cell lines. The International Journal of Biochemistry \& Cell Biology 78, 248-259 (2016).

28. Quattrini, L. et al. Imidazo[1,2-a]pyridine Derivatives as Aldehyde Dehydrogenase Inhibitors: Novel Chemotypes to Target Glioblastoma Stem Cells. J Med Chem 63, 4603-4616 (2020).

29. Quattrini, L. et al. Progress in the Field of Aldehyde Dehydrogenase Inhibitors: Novel Imidazo[1,2-a]pyridines against the 1A Family. ACS Med Chem Lett 11, 963970 (2020).

30. Shahcheraghi, S. H. et al. Therapeutic Potential of Curcumin in the Treatment of Glioblastoma Multiforme. Curr Pharm Des 25, 333-342 (2019).

31. Purkayastha, S. et al. Curcumin blocks brain tumor formation. Brain Res 1266, 130-138 (2009).

32. Gersey, Z. C. et al. Curcumin decreases malignant characteristics of glioblastoma stem cells via induction of reactive oxygen species. BMC Cancer 17, 99 (2017).

33. Nelson, K. M. et al. The Essential Medicinal Chemistry of Curcumin: Miniperspective. J. Med. Chem. 60, 1620-1637 (2017).

34. Park, K.-S. et al. A curcumin-based molecular probe for near-infrared fluorescence imaging of tau fibrils in Alzheimer's disease. Org Biomol Chem 13, 11194-11199 (2015).

35. Wang, $X$. et al. Curcumin exerts its tumor suppressive function via inhibition of NEDD4 oncoprotein in glioma cancer cells. Int J Oncol 51, 467-477 (2017).

36. Kamada, K. et al. Boron Difluoride Curcuminoid Fluorophores with Enhanced Two-Photon Excited Fluorescence Emission and Versatile Living-Cell Imaging Properties. Chem. Eur. J. 22, 5219-5232 (2016).

37. Hishii, M., Matsumoto, T. \& Arai, H. Diagnosis and Treatment of Early-Stage Glioblastoma. Asian J Neurosurg 14, 589-592 (2019).

38. Caprioglio, D. et al. Triazole-curcuminoids: A new class of derivatives for 'tuning' curcumin bioactivities? Bioorganic \& Medicinal Chemistry 24, 140-152 (2016).

39. Koeberle, A. et al. SAR studies on curcumin's pro-inflammatory targets: discovery of prenylated pyrazolocurcuminoids as potent and selective novel inhibitors of 5lipoxygenase. J Med Chem 57, 5638-5648 (2014). 
40. Caldarelli, A., Penucchini, E., Caprioglio, D., Genazzani, A. A. \& Minassi, A. Synthesis and tubulin-binding properties of non-symmetrical click C5-curcuminoids. Bioorg Med Chem 21, 5510-5517 (2013).

41. Minassi, A., Sánchez-Duffhues, G., Collado, J. A., Muñoz, E. \& Appendino, G. Dissecting the pharmacophore of curcumin. Which structural element is critical for which action? J Nat Prod 76, 1105-1112 (2013).

42. Pabon, H. J. J. A synthesis of curcumin and related compounds. Recl. Trav. Chim. Pays-Bas 83, 379-386 (1964).

43. Cai, L., Innis, R. B. \& Pike, V. W. Radioligand development for PET imaging of beta-amyloid (Abeta)--current status. Curr Med Chem 14, 19-52 (2007).

44. Agalave, S. G., Maujan, S. R. \& Pore, V. S. Click Chemistry: 1,2,3-Triazoles as Pharmacophores. Chem. Asian J. 6, 2696-2718 (2011).

45. Anand, P., Kunnumakkara, A. B., Newman, R. A. \& Aggarwal, B. B. Bioavailability of curcumin: problems and promises. Mol Pharm 4, 807-818 (2007).

46. Van Nong, $\mathrm{H}$. et al. Fabrication and vibration characterization of curcumin extracted from turmeric (Curcuma longa) rhizomes of the northern Vietnam. SpringerPlus 5, 1147 (2016).

47. Morgan, C. A., Parajuli, B., Buchman, C. D., Dria, K. \& Hurley, T. D. N,Ndiethylaminobenzaldehyde (DEAB) as a substrate and mechanism-based inhibitor for human ALDH isoenzymes. Chem Biol Interact 234, 18-28 (2015).

48. Díez Valle, R., Hadjipanayis, C. G. \& Stummer, W. Established and emerging uses of 5-ALA in the brain: an overview. J Neurooncol 141, 487-494 (2019).

49. Neira, J. A. et al. Aggressive resection at the infiltrative margins of glioblastoma facilitated by intraoperative fluorescein guidance. J Neurosurg 127, 111-122 (2017).

50. Katsevman, G. A., Turner, R. C., Urhie, O., Voelker, J. L. \& Bhatia, S. Utility of sodium fluorescein for achieving resection targets in glioblastoma: increased gross- or near-total resections and prolonged survival. J Neurosurg 132, 914-920 (2019).

51. Azzalin, A. et al. A New Pathway Promotes Adaptation of Human Glioblastoma Cells to Glucose Starvation. Cells 9, 1249 (2020).

52. Szatmari, T. et al. Detailed characterization of the mouse glioma 261 tumor model for experimental glioblastoma therapy. Cancer Science 97, 546-553 (2006). 


\section{Figure 1}

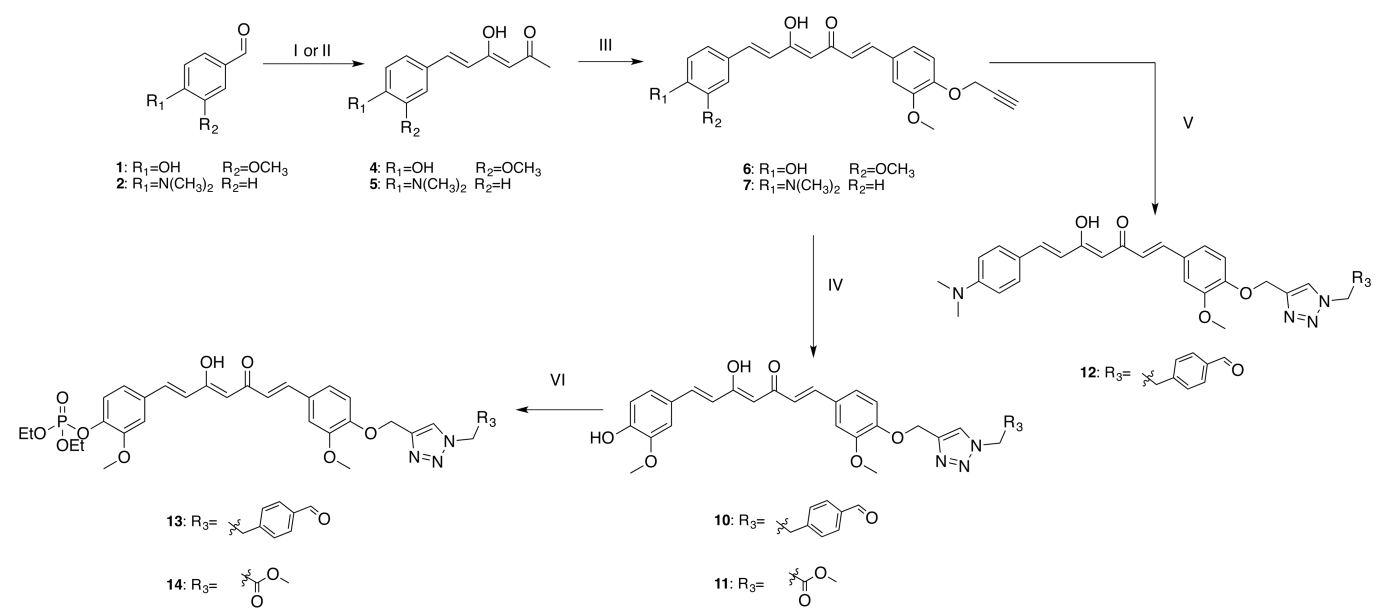

Figure 1. Synthesis of compounds $10,11,12,13$ and 14. I) acetyl acetone, boron oxide, trimethyl borate, $n$-butylamine, DMF; II) acetyl acetone, boron oxide, trimethyl borate, $n$-butylamine, EtOAc; III) boron oxide, trimethyl borate, $n$ butylamine, DMF; IV) $\mathrm{CuSO}_{4}, \mathrm{Na}$-ascorbate, $\mathrm{t}-\mathrm{BuOH} / \mathrm{H}_{2} \mathrm{O} / \mathrm{CH}_{3} \mathrm{CN} 2: 1: 1$; V) $\mathrm{CuSO}_{4}, \mathrm{Na}$-ascorbate, $\mathrm{t}-\mathrm{BuOH} / \mathrm{H}_{2} \mathrm{O} / \mathrm{CH}_{3} \mathrm{CN}$ 2:1:1; VI) diethylchlorophosphate, TEA, $\mathrm{CH}_{2} \mathrm{Cl}_{2}$. 


\section{Figure 2}

A

\begin{tabular}{|l|l|l|l|}
\hline Molecule & Abs $(\mathrm{nm})$ & Ex $(\mathrm{nm})$ & Em $(\mathrm{nm})$ \\
\hline Probe 10 & 420 & 440 & 560 \\
\hline
\end{tabular}

C

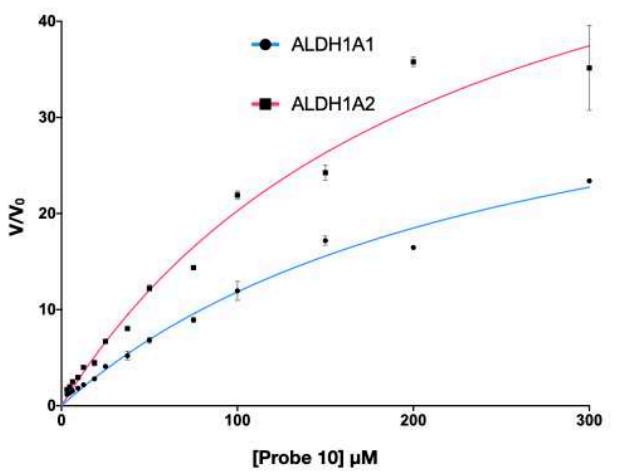

B

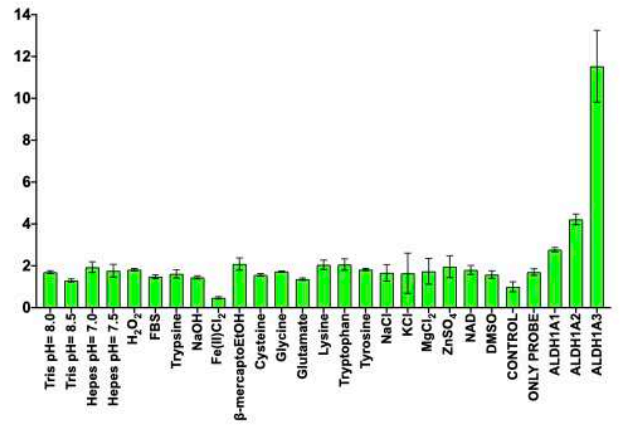

D

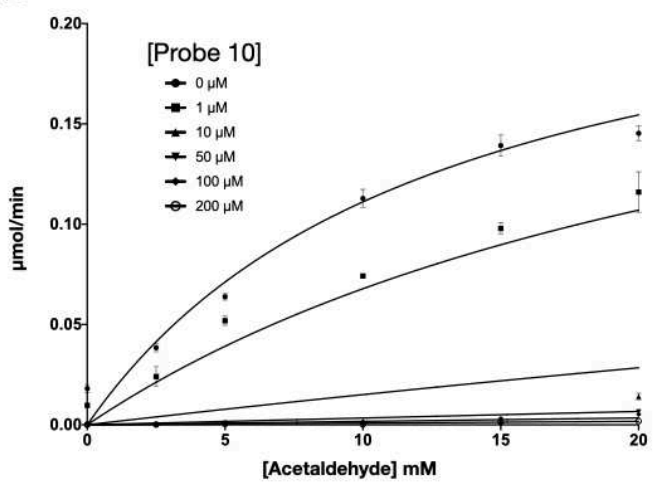

E

\begin{tabular}{|c|c|c|c|c|c|c|}
\hline Isoform & $\mathrm{K}_{\mathrm{d}}$ & $\mathrm{R}^{2}$ & $\mathrm{~K}_{\mathrm{M}}(\mu \mathrm{M})$ & $\mathrm{R}^{2}$ & $\mathrm{~K}_{\mathrm{i}}(\mu \mathrm{M})$ & $\mathrm{R}^{2}$ \\
\hline ALDH1A1 & 31.1 & 0.98 & 255.2 & 0.99 & $/$ & $/$ \\
\hline ALDH1A2 & 36.9 & 0.98 & 220.0 & 0.98 & $/$ & $/$ \\
\hline ALDH1A3 & 38.2 & 0.96 & $/$ & $/$ & 0.88 & 0.97 \\
\hline
\end{tabular}

Figure 2. A-Evaluation of the absorbance, excitation and emission wavelengths of the compound Probe 10 at a fixed concentration of $10 \mu \mathrm{M}$ in the SEC buffer. B- Increase of Probe 10 fluorescence intensity in presence of various biomolecules reactive at concentrations of $100 \mu \mathrm{M}$. For all assays, Probe 10 was used at $10 \mu \mathrm{M}$ final concentration. C- Kd graph of the complex between Probe $\mathbf{1 0}$ at fixed concentration and various concentration of ALDH1A1 and ALDH1A2. D$\mathrm{Ki}$ graph of the complex between Probe 10 and ALDH1A3, in presence of different substrate and probe concentration. Probe $\mathbf{1 0}$ was analysed as potential full competitive inhibitor. E- Kd, Ki and $\mathrm{R}^{2}$ of the three protein-probe complexes. 


\section{Figure 3}

A

\begin{tabular}{|l|l|l|l|}
\hline Molecule & Abs $(\mathrm{nm})$ & Ex $(\mathrm{nm})$ & Em $(\mathrm{nm})$ \\
\hline Probe 11 & 410 & 420 & 545 \\
\hline
\end{tabular}

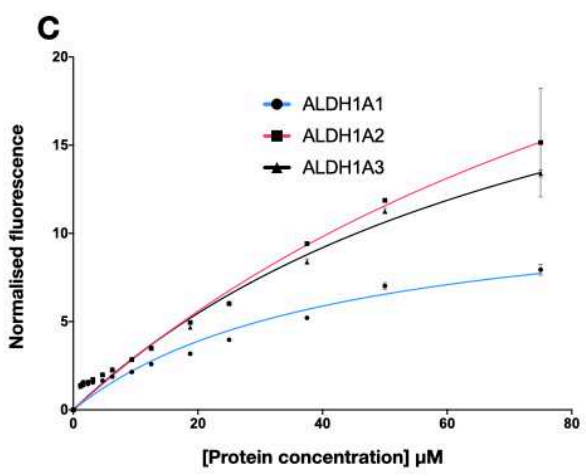

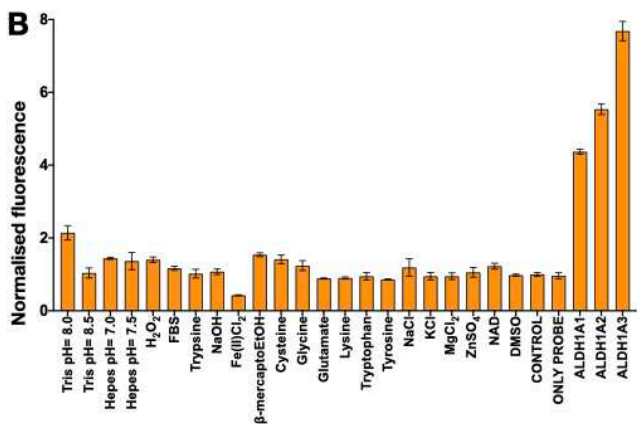

D

\begin{tabular}{|c|c|c|}
\hline Isoform & $\mathrm{K}_{\mathrm{d}}(\mu \mathrm{M})$ & $\mathrm{R}^{2}$ \\
\hline ALDH1A1 & 42.4 & 0.93 \\
\hline ALDH1A2 & 124.8 & 0.98 \\
\hline ALDH1A3 & 84.3 & 0.98 \\
\hline
\end{tabular}

Figure 3. A-Evaluation of the absorbance, excitation, and emission wavelengths of the compound Probe $\mathbf{1 1}$ at a fixed concentration of $10 \mu \mathrm{M}$ in the SEC buffer. B- Increase of Probe 11 fluorescence intensity in presence of various biomolecules reactive at concentrations of $100 \mu \mathrm{M}$. For all assays, Probe 11 was used at $10 \mu \mathrm{M}$ final concentration. C- Kd graph of the complex between Probe 11 at fixed concentration and various concentration of ALDH1A1, ALDH1A2 and ALDH1A3. D- Kd and $R^{2}$ of the three protein-probe complexes. 
Figure 4
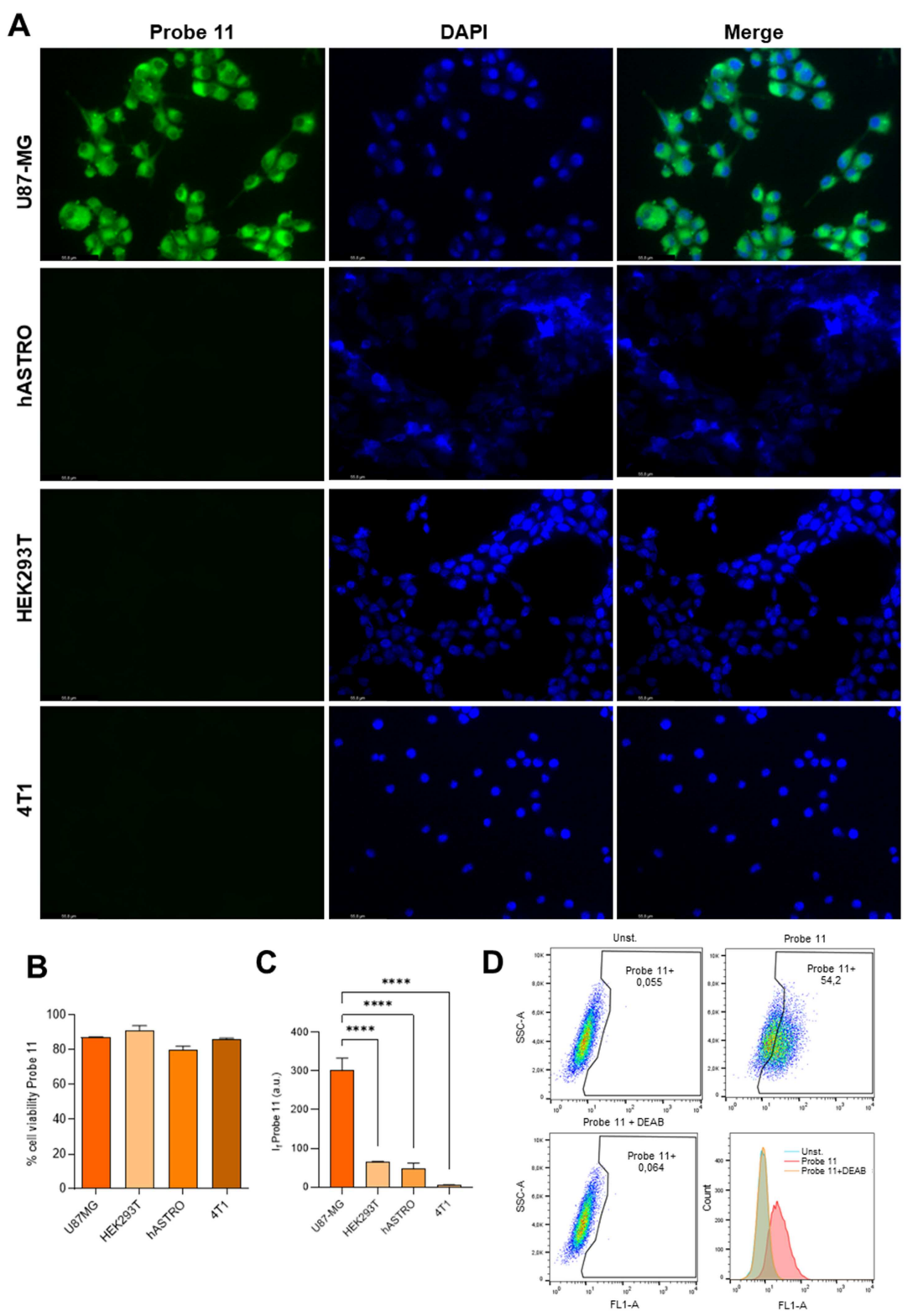

Figure 4. Probe 11 is selective on U87 ALDH1A3 positive cells. A- Confocal fluorescence microscope images for probe 11 detection in different cell lines at $10 \mu \mathrm{M}$, after $2 \mathrm{~h}$ of incubation. B- Cell viability at $10 \mu \mathrm{M}$ of probe 11 . C- Relative fluorescence intensity of the images from A. D- Flow cytometry analysis of U87MG cells unstained, stained with probe $11(10 \mu \mathrm{M})$ with or without DEAB $(1 \mu \mathrm{M})$. 
(c) Histographic profiles of unstained, stained with probe $11(10 \mu \mathrm{M})$ with or without DEAB $(1 \mu \mathrm{M})$. P value: ${ }^{* * * *} p<0.0001$. 


\section{Figure 5}
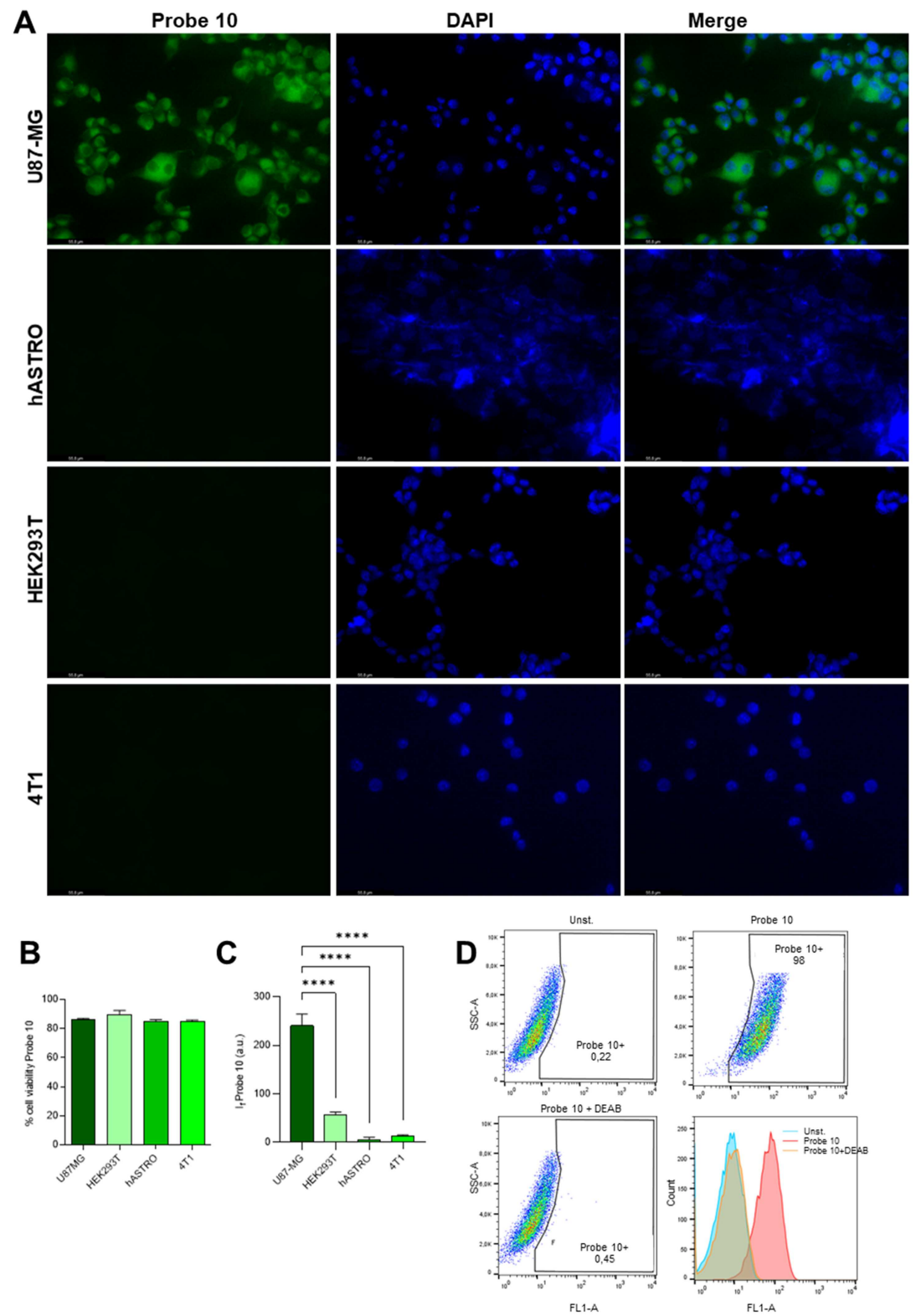

Figure 5. Probe 10 is selective on U87 ALDH1A3 positive cells. A- Confocal fluorescence microscope images for probe 10 detection in different cell lines at $10 \mu \mathrm{M}$, after $2 \mathrm{~h}$ of incubation. B- Cell viability at $10 \mu \mathrm{M}$ of probe 10 . C- Relative fluorescence intensity of the images from A. D- Flow cytometry analysis of U87MG cells unstained, stained with probe $10(10 \mu \mathrm{M})$ with or without DEAB $(1 \mu \mathrm{M})$. 
(c) Histographic profiles of unstained, stained with probe $10(10 \mu \mathrm{M})$ with or without DEAB $(1 \mu \mathrm{M})$. P value: ${ }^{* * *} p<0.0001$. 


\section{Figure 6}
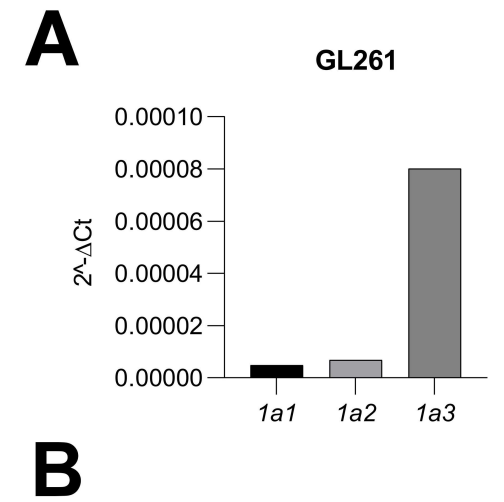

probe 11
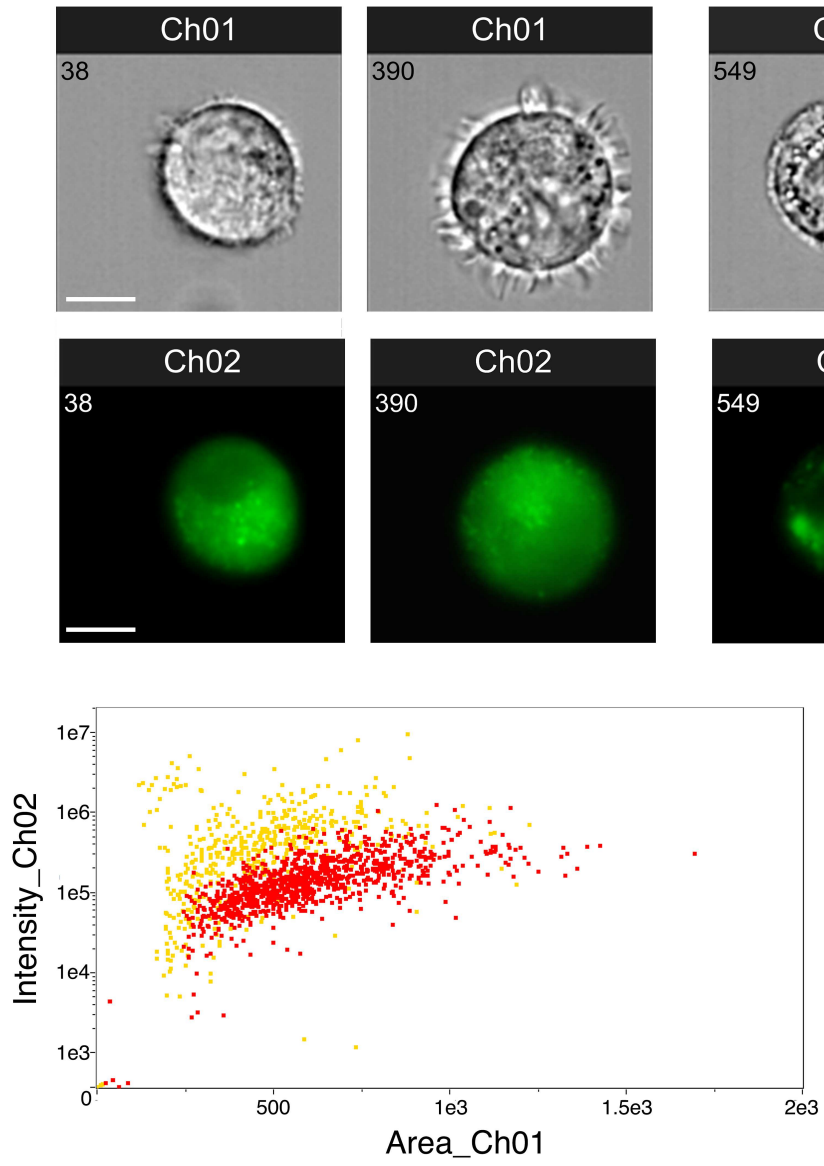

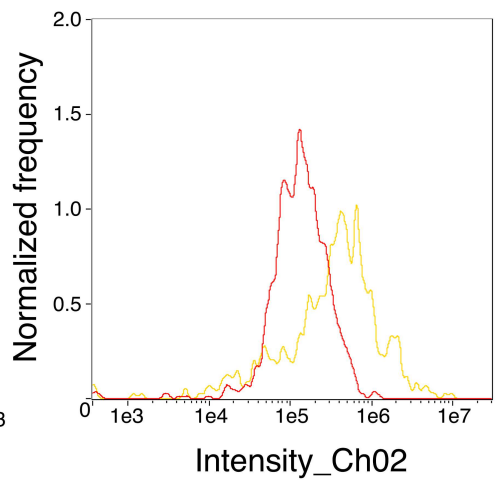

probe 10
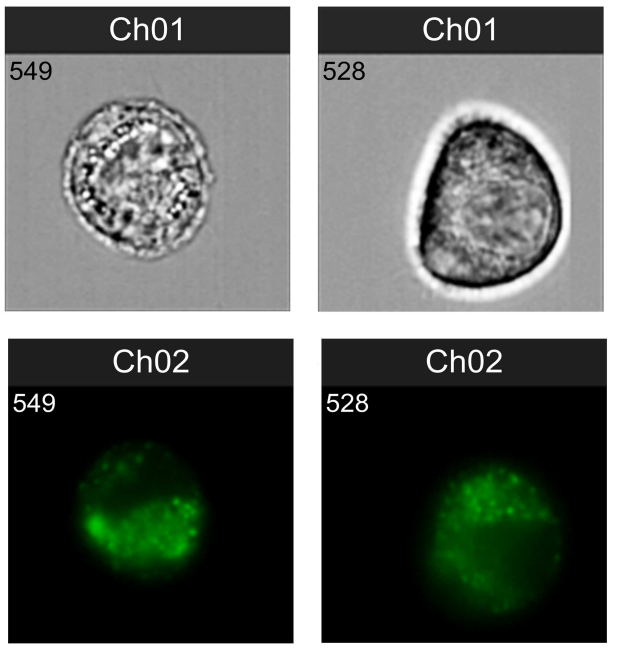

Intensity_Ch02 
Figure 6. In vitro experiments showing that ALDH1A3 is the most expressed isoform in GL261 murine glioma cells and both fluorescent substrates enter and label the same cells. A) Results of quantitative rtPCR showing the levels of expression of ALDH1A1 (1a1), ALDH1A2 (1a2) and ALDH1A3 (1a3) in murine GL261 cells. ALDH1A3 is significantly more expressed than the other isoforms. B) Living GL261 cells were analyzed through an ImageStreamX Markll using two channels: brightfield (Ch 01) and fluorescence (Ch 02) after one hour incubation in either compound probe 11 or probe 10 incubation cells were thoroughly washed in PBS and analyzed. Two different representative cells are shown for each compound. From above, row 1 brightfield images (Ch 01), row 2 fluorescent images (Ch 02). "In Focus Cells" were identified based on the "Gradient Root Mean Square (RMS) Contrast Feature" that captures in focus images of cells identified by high normalized pixel intensity gradient (RMS values) derived from Ch 01; then, a scatter plot of the "Aspect Ratio Feature" versus brightfield "Area Feature" was used to identify single cells (singlets) from debris or cell clumps based on high aspect ratio and low area value; finally, the two samples were merged to compare fluorescence intensity variations in the histogram and a dot plot (Area vs Intensity). Scale bars: $5 \mu \mathrm{m}$ are the same in all images. 


\section{Figure 7}
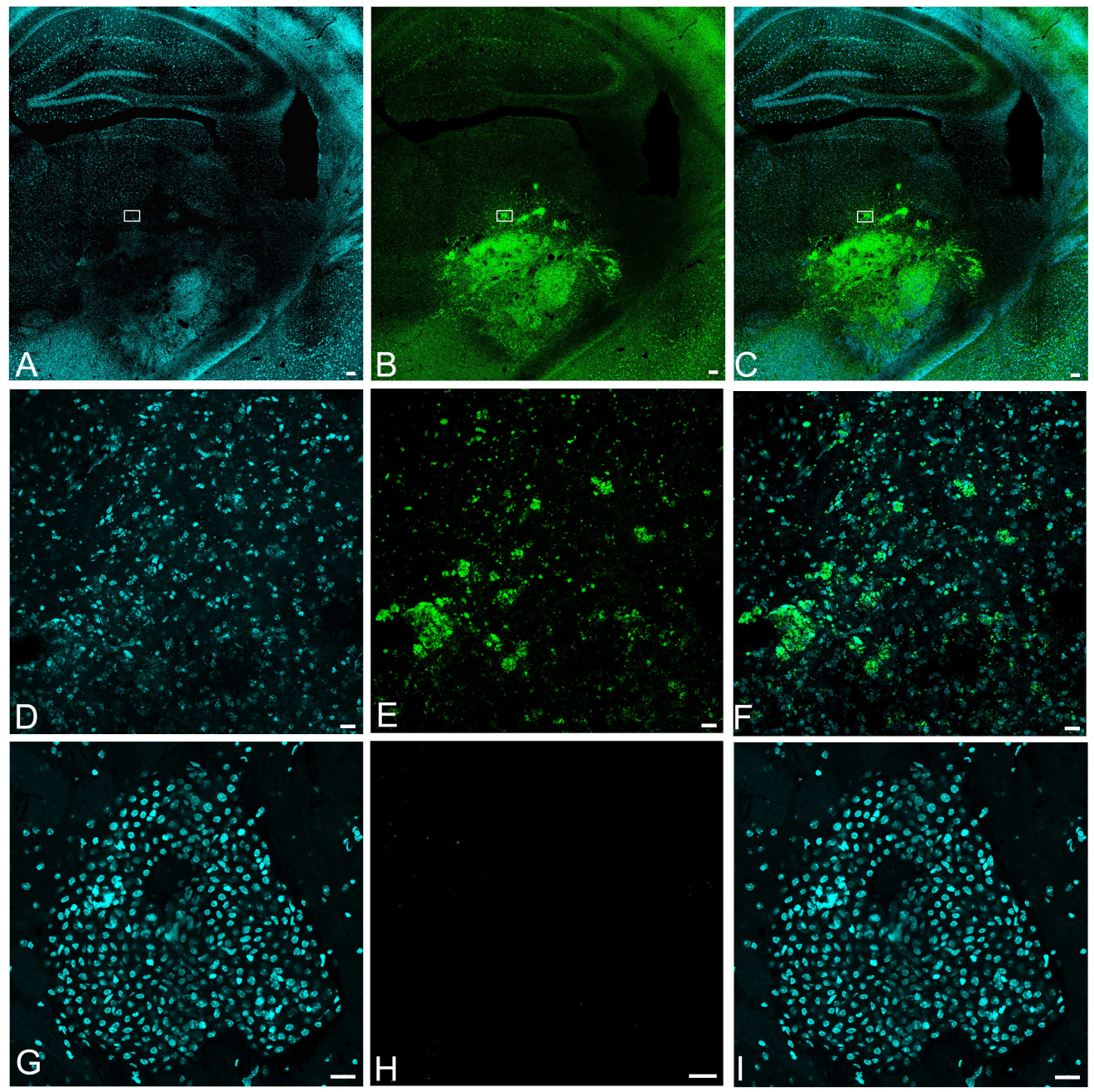

Figure 7. In vivo labeling by the fluorescent ALDH1A3 substrates of GL261 cells growing and infiltrating the host brain 6 days after the initial inoculum. A, B and C) Confocal images showing, under different fluorescence conditions, the same coronal section of a tumor-bearing brain in an animal i.p. injected with compound probe $10 \mathrm{In}$ all images the area boxed is the same and it is shown at higher magnification in figures $6 \mathrm{D}, 6 \mathrm{E}$ and $6 \mathrm{~F}$. In $6 \mathrm{~A}$ Cell nuclei are stained by DAPI, in 6B GL261 cells containing probe 10 fluorescence in green. Most of the fluorescence comes from glioma cells growing in the left striatum and adjacent structures that have taken up and metabolized probe 10 . Scale bars: $25 \mu \mathrm{M}$. In $6 \mathrm{C}$ the image shows the double fluorescence of DAPI and probe 10 together. 
D, E and F) Confocal images showing at higher magnification the area boxed in fig. $6 \mathrm{~A}, 6 \mathrm{~B}$ and $6 \mathrm{C}$. Fluorescence of probe 10 is mostly contained in the cytoplasm. Scale bars: $25 \mu \mathrm{M}$.

G, $\mathbf{H}$ and I) Confocal images showing, under different fluorescence conditions, the same coronal section of a tumor-bearing brain in an animal i.p. injected with compound probe 10 that does not penetrate to any appreciable level the tumor cells in vivo, despite penetrating GL261 cells in vitro. Scale bars: $25 \mu \mathrm{M}$. iConfocal image under excitation and filtering conditions appropriate both for DAPI and probe 10 , no fluorescence due to probe 10 is visible despite the abundance of tumor cells. 


\section{Supplementary Files}

This is a list of supplementary files associated with this preprint. Click to download.

- GelardiCaprioglioetallSI.docx

- Gelardinrreportingsummary.pdf 